\title{
Drug-Related Pneumonitis in Cancer Treatment during the COVID-19 Era
}

\author{
Sara Cherri ${ }^{1, *}$, Silvia Noventa ${ }^{1}{ }^{\infty}$, Martina Fanelli ${ }^{2}$, Giulio Calandra ${ }^{3}$, Tiziana Prochilo ${ }^{1}$, Claudio Bnà ${ }^{3}$, \\ Giordano Savelli ${ }^{4} \mathbb{D}$ and Alberto Zaniboni ${ }^{1}$
}

1 Unit of Medical Oncology, Department of Oncology, Fondazione Poliambulanza, 25124 Brescia, Italy; silvia.noventa@poliambulanza.it (S.N.); tiziana.prochilo@poliambulanza.it (T.P.); alberto.zaniboni@poliambulanza.it (A.Z.)

2 Medical Oncology Unit, University Hospital of Modena, 41124 Modena, Italy; martinafun89@gmail.com

3 Unit of Radiology, Department of Diagnostic Imaging, Fondazione Poliambulanza, 25124 Brescia, Italy; giulio.calandra@poliambulanza.it (G.C.); claudio.bna@poliambulanza.it (C.B.)

4 Nuclear Medicine Department, Fondazione Poliambulanza, 25124 Brescia, Italy; giordano.savelli@poliambulanza.it

* Correspondence: sara.cherri@poliambulanza.it; Tel.: +39-03035151; Fax: +39-0303518270

check for updates

Citation: Cherri, S.; Noventa, S.; Fanelli, M.; Calandra, G.; Prochilo, T.; Bnà, C.; Savelli, G.; Zaniboni, A. Drug-Related Pneumonitis in Cancer Treatment during the COVID-19 Era. Cancers 2021, 13, 1052. https:// doi.org/10.3390/cancers13051052

Academic Editor: Sanjay Gupta

Received: 15 February 2021

Accepted: 24 February 2021

Published: 2 March 2021

Publisher's Note: MDPI stays neutral with regard to jurisdictional claims in published maps and institutional affiliations.

Copyright: (c) 2021 by the authors. Licensee MDPI, Basel, Switzerland. This article is an open access article distributed under the terms and conditions of the Creative Commons Attribution (CC BY) license (https:// creativecommons.org/licenses/by/ $4.0 /)$.
Simple Summary: Interstitial lung disease is a group of diseases characterized by chronic lung inflammation that can be related to oncological treatments, such as traditional chemotherapy drugs and the newest targeted therapies and immunotherapies. Awareness about this potentially fatal adverse event is paramount in patient management and to make a conscious therapeutic choice. It represents a differential diagnostic challenge, especially in the context of the COVID-19 pandemic. Our aim is to describe the incidence and characteristics of this adverse event across oncological treatment groups and to promote greater knowledge about this important toxicity.

Abstract: Interstitial lung disease is recognized as a group of diseases with a different etiopathogenesis characterized by chronic lung inflammation with the accumulation of inflammatory cells, lymphocytes and macrophages, and the consequent release of proinflammatory cytokines. Various degrees of pulmonary fibrosis can be associated with this inflammatory condition. Interstitial lung disease related to oncological drugs is a relevant problem in clinical practice. The etiopathogenetic mechanisms underlying this adverse event are not completely known but can be partly explained by the mechanism of action of the drug involved. Therefore, knowledge of the relevance of this potentially fatal adverse event supported by the reported safety data of pivotal studies becomes fundamental in the management of patients. The prompt diagnosis of drug-related pneumonia and the consequent differential diagnosis with other forms of pneumonia allow a rapid suspension of treatment and the establishment of an immunosuppressive treatment if necessary. In the context of the health emergency related to SARS CoV2 infection and COVID-19-related interstitial lung disease, such knowledge holds decisive relevance in the conscious choice of cancer treatments. Our intent was to describe the oncological drugs most correlated with this adverse event by reporting, where possible, the percentages of insurgency in pivotal studies to provide an overview and therefore promote greater awareness of this important toxicity related to oncological treatment.

Keywords: lung toxicity; interstitial lung disease; pneumonitis; cancer treatment; target therapy; chemotherapy; immunotherapy; COVID-19

\section{Introduction}

On 9 January 2020, a new coronavirus, SARS-CoV-2, was defined as the causative agent of a cluster of pneumonia cases reported in Wuhan, China. The disease caused by the new coronavirus was named COVID-19. On 11 March 2020, the World Health Organization (WHO) Director General indicated that the spread of COVID-19 was no longer an epidemic 
confined to certain geographical areas, but a pandemic spread throughout the planet. Thus, a dramatic period began worldwide that led to the collapse of the health system as we know it. Within this context, medical oncology has had to question the benefit-risk ratio of cancer treatments during the pandemic not only because of the increased risk of contagion for patients when going to the hospital to receive cancer treatments, but also because of worrying data about the impact of cancer on the prognosis of SARS-CoV-2 infection [1].

SARS-CoV-2 infection does not present with the same severity in all patients, in particular, three potential scenarios are recognized: mild, severe and critical illness. In mild disease, mild pneumonia or no pneumonia develops, and usually in this form, symptoms of viral upper respiratory tract infection prevail. Conversely, critical illness is characterized by severe pneumonia with a systemic presentation and potential multiorgan failure. X-ray images are characterized by the presence of interstitial lung disease with uneven ground glass opacities and uneven consolidation in the intermediate, outer and subpleural areas of the lung [2].

Many cancer drugs can also cause interstitial lung damage [3]. Pulmonary toxicities are not among the most common adverse events of drugs used in the treatment of solid tumors; however, there are no clear data on their incidence. In this context, case reports and real-life data can make a valuable contribution to better quantify the impact of this toxicity, which in some cases can be fatal. It is important to take this toxicity into account in the decision-making process and, second, to suspect drug-related interstitial lung disease in case of suggestive symptoms to promptly suspend the therapy when necessary. Therefore, the choice of oncological treatment during the era of COVID-19 can be difficult. We conducted a qualitative review of the evidence in the literature regarding pulmonary toxicity from oncological drugs, focusing in particular on immunotherapy, target therapy and conjugated antibodies recently approved by the FDA (Food and Drug Administration) and EMA (European Medicines Agency) for the treatment of solid tumors with the aim of understanding the relevance of this issue.

\section{Chemotherapy and Lung Toxicity}

Interstitial pneumonitis related to chemotherapy drugs represents a relevant oncological problem that has been investigated both in preclinical and clinical studies to understand the underlying mechanisms. Pulmonary toxicity of some of the older chemotherapy standard drugs may be dose-dependent, i.e., bleomycin [4], or it can be observed several years after their use, i.e., cyclophosphamide [5]. To date, there are no tools to prevent the onset of interstitial pneumonitis other than the careful clinical evaluation of patients who develop respiratory symptoms and radiological monitoring in the most fragile subjects. Table 1 presents the main chemotherapy drugs that can lead to the development of interstitial pneumonia.

Bleomycin is a chemotherapy drug that is classically related to such toxicity, as noted in the first clinical trials in the 1960s. A prevalence of pulmonary toxicity of $40-45 \%$ has been reported with regimens including bleomycin, with a fatal outcome in 1-3\% of these cases. There is currently no protocol to prevent this adverse event; however, some risk factors are recognized, such as the cumulative dose of bleomycin, reduction in glomerular filtration rate (GFR), elevated creatinine and advanced age [6]. With regard to the mechanism of lung damage induced by bleomycin, a possible interpretative key is oxidative damage, which could lead to pulmonary toxicity in subjects with deficiency of the enzyme that physiologically deactivates bleomycin hydrolase, leading to the release of inflammatory cytokines and consequent pulmonary fibrosis [7]. Bleomycin hydrolase, an enzyme that degrades bleomycin, is active in all tissues except for skin and lung, partly explaining the drug's specific toxicity to these organs. Studies examining the different susceptibilities of mouse strains to bleomycin reveal that a bleomycin-resistant strain produces considerably more bleomycin hydrolase than a bleomycin-sensitive strain. The acute lung damage observed in bleomycin-sensitive mice was attributed to DNA strand splitting, resulting in chromosomal damage. The chronic fibrotic response to bleomycin- 
induced damage is associated with an acquired loss of bleomycin hydrolase activity and is mediated by the migration of activated effector cells into the lung with the release of proinflammatory mediators. Nude (athymic) mice are resistant to bleomycin-induced lung damage, suggesting that the inflammatory process is necessary for the pathogenesis of the disease. Proinflammatory lung injury mechanisms, similar to those reported in bleomycin studies, are also observed with methotrexate and cyclophosphamide $[8,9]$. Studies have demonstrated that in response to excess free radicals resulting from methotrexate use, an interleukin response may be induced with activation of p38 mitogen-activated protein kinases (MAPK p38), kinases involved in pulmonary inflammation and fibrosis [10,11]. In the case of cyclophosphamide, inflammatory processes are also described with an increased inflammatory cascade (TGF $\beta$, fibronectin and procollagen) in response to DNA damage and oxidative stress.

Despite a reduced incidence, drug-related reports of interstitial pneumonia also involve other widely used chemotherapeutic drugs, such as platinoids, taxanes and gemcitabine (see Table 1). With regard to gemcitabine, a systematic review on severe lung toxicity reported an incidence of up to 5\% [12]. The clinical presentation is mostly nonspecific and requires a diagnosis of exclusion from other causes of interstitial pneumonitis. The predominant radiographic pattern is represented by reticulo-nodular interstitial infiltrates. It has been postulated that the pathophysiological mechanism of gemcitabine-mediated lung injury is a cytokine-mediated inflammatory reaction of the capillary-alveolar walls, with consequent alteration of membrane permeability [13]. For platinoids, when used alone, pulmonary toxicities are very rare, if not anecdotal. On the other hand, interstitial pneumonia associated with the use of taxanes is of greater relevance, with an incidence of grade 3 or higher in approximately $1 \%$ to $5 \%$ of patients receiving paclitaxel or docetaxel at conventional doses thrice weekly [14]. As previously mentioned, an increased risk is reported in the combined treatments [15].

Table 1. Chemotherapeutic agents related to lung injury in the treatment of solid tumors.

\begin{tabular}{|c|c|c|c|}
\hline Drug & Class & Incidence of Lung Toxicity (\%) * & Main Patterns of Lung Toxicity \\
\hline Bleomycin $[16,17]$ & \multirow{3}{*}{ Antitumour antibiotics } & $10 \%{ }^{1}$ & $\begin{array}{c}\text { Interstitial pneumonitis } \\
\text { Pulmonary fibrosis } \\
\text { COP }^{2}\end{array}$ \\
\hline Mitomycin C [18,19] & & $5-10 \%$ & $\begin{array}{c}\text { Interstitial pneumonitis } \\
\text { Pulmonary fibrosis } \\
\text { PVOD }^{3}\end{array}$ \\
\hline Anthracyclines [20] & & Rare & Pulmonary fibrosis \\
\hline $\begin{array}{l}\text { Cyclophosphamide } \\
\text { Ifosfamide }[8,21]\end{array}$ & $\begin{array}{l}\text { Alkylating agents } \\
\text { Nitrogen mustards }\end{array}$ & $<1 \%$ & $\begin{array}{l}\text { Interstitial pneumonitis } \\
\text { Interstitial fibrosis }\end{array}$ \\
\hline $\begin{array}{l}\text { Carmustine [22] } \\
\text { Lomustine } \\
\text { Fotemustine }\end{array}$ & Nitrosoureas & $10-30 \%$ & $\begin{array}{l}\text { Intraalveolar fibrosis } \\
\text { Bilateral pleural thickening } \\
\text { Pulmonary hypertension }\end{array}$ \\
\hline Temozolomide $[23,24]$ & Triazene compounds & $<1 \% 4$ & Pneumothorax \\
\hline Cisplatin [25] & \multirow{3}{*}{ Platinoids } & Rare & Eosinophilic pneumonia \\
\hline Carboplatin [26] & & Rare & Pulmonary fibrosis \\
\hline Oxalplatin $[27,28]$ & & $<1 \%(0-4 \%)$ & $\begin{array}{c}\text { Interstitial pneumonitis } \\
\text { Pulmonary fibrosis } \\
\text { COP }^{2}\end{array}$ \\
\hline
\end{tabular}


Table 1. Cont.

\begin{tabular}{|c|c|c|c|}
\hline Drug & Class & Incidence of Lung Toxicity (\%) * & Main Patterns of Lung Toxicity \\
\hline Methotrexate [9-11] & \multirow[b]{3}{*}{ Antimetabolites } & $\begin{array}{c}3-4 \% \\
\text { (up to } 10 \% \text { in arthritis patients) }\end{array}$ & $\begin{array}{l}\text { Hypersensitivity pneumonitis } \\
\text { Obliterating bronchiolitis } \\
\text { Intraalveolar fibrosis }\end{array}$ \\
\hline Pemetrexed $[29,30]$ & & Rare & Interstitial pneumonitis \\
\hline Gemcitabine $[12,31,32]$ & & $\begin{array}{c}1-4 \% \\
\text { (up to } 20 \% \text { if with taxanes) }\end{array}$ & $\begin{array}{c}\text { Interstitial pneumonitis } \\
\text { Interstitial lung fibrosis } \\
\text { PVOD }^{3} \\
\text { Non-cardiogenic pulmonary oedema } \\
\text { AIP/ARDS }{ }^{5} \\
\text { Diffuse alveolar haemorrhage } \\
\text { Pleural effusion } \\
\downarrow \text { DLCO (normal FEV } \text { eFVC) }^{\text {D }}\end{array}$ \\
\hline Topotecan [33] & \multirow{3}{*}{ Topoisomerase inhibitors } & Rare & $\begin{array}{l}\text { Diffuse alveolar damage } \\
\text { Interstitial pneumonitis } \\
\text { Obliterating bronchiolitis }\end{array}$ \\
\hline Irinotecan [34-36] & & $\begin{array}{c}1-2 \% \\
\text { (up to } 20 \% \text { in lung cancer } \\
\text { with paclitaxel) }\end{array}$ & Interstitial pneumonitis \\
\hline Etoposide [37] & & Rare & $\begin{array}{l}\text { Interstitial and alveolar infiltrates } \\
\text { Pulmonary fibrosis }\end{array}$ \\
\hline $\begin{array}{l}\text { Paclitaxel }[38,39] \\
\text { Docetaxel }[13,40]\end{array}$ & \multirow[t]{2}{*}{ Antimicrotubule agents } & $\begin{array}{l}1-5 \% \text { in three-weekly schedule } \\
\text { (up to } 20 \% \text { if with gemcitabine } \\
\text { and up to } 30 \% \text { with radiotherapy) }\end{array}$ & $\begin{array}{c}\text { Interstitial pneumonitis } \\
\text { Hypersensitivity pneumonitis } \\
\text { Pulmonary fibrosis } \\
\text { AIP / ARDS } 5 \\
\text { Pleural effusions (capillary leak } \\
\text { syndrome, especially for docetaxel) }\end{array}$ \\
\hline Vinorelbine [41] & & Rare & Interstitial pneumonitis \\
\hline
\end{tabular}

* Information regarding pivotal clinical trials or summary of drug/product characteristics is obtained from the literature. Information can be very different, depending on the sources, i.e., the criteria used to define pulmonary toxicity (clinical, radiological, etc.), the type of scheme in which the drug is contained, or the presence of concomitant radiotherapy and the type of patients and diseases analyzed (presence of possible risk factors for major lung damage). It was occasionally not possible to estimate a realistic incidence given the rarity of the event (mostly case reports) and because the drug is typically used in combination with other potentially toxic treatments. Therefore, the true incidence is often unknown, and we can only say that it is a rare/uncommon effect. ${ }^{1}$ The incidence can be very different depending on the treatment regimen, i.e., from $5 \%$ to $16 \%$ in germ cell tumors treated with BEP (bleomycin, etoposide, cisplatin) or CVB (cisplatin, vinblastine, bleomycin) and from $10 \%$ to $53 \%$ in Hodgkin's lymphomas treated with ABVD (doxorubicin, bleomycin, vinblastine, dacarbazine). ${ }^{2} \mathrm{COP}=$ Cryptogenic Organizing Pneumonia ${ }^{3}$ PVOD $=$ Pulmonary veno-occlusive disease ${ }^{4}$ In gliomas, the incidence of nitrosourea-mediated lung toxicity is probably lower due to the low cumulative doses that are reached or the early progression of disease/death. ${ }^{5}$ AIP = Acute Interstitial Pneumonia; ARDS = Acute Respiratory Distress Syndrome.

\section{Target Therapies and Lung Toxicity}

This list of target therapies leading to ILD is certainly destined to extend the updated safety data of drugs that have been used in clinical oncology for the past few years [42] For example, the FDA recently published updated safety data for the cyclin inhibitor drugs palbociclib, ribociclib and abemaciclib, warning that these drugs can cause rare but serious pneumonitis [43]. This topic will also deserve careful consideration in the coming years given that this type of toxicity was reported for drugs not yet approved in Europe but that are likely to be available in the next few years. Table 2 reports target therapies causing lung injury. 
Table 2. Incidence of pneumonitis with targeted cancer therapies approved by the FDA and EMA in the treatment of solid tumors.

\begin{tabular}{|c|c|c|c|c|}
\hline \multicolumn{2}{|c|}{ Class } & Drug & Use & $\begin{array}{l}\text { Incidence of Lung Toxicity } \\
(\%) \text {, Any Grade * }\end{array}$ \\
\hline \multirow{18}{*}{$\begin{array}{l}\text { TKIs (Tyrosine } \\
\text { Kinase Inhibitors) }\end{array}$} & \multirow{4}{*}{ EGFR inhibitors } & Gefitinib $[44,45]$ & EGFR-mutated advanced NSCLC & $1.6 \%$ \\
\hline & & Erlotinib $[44,45]$ & EGFR-mutated advanced NSCLC & $0.8-1.6 \%$ \\
\hline & & Afatinib $[44,45]$ & EGFR-mutated advanced NSCLC & $0.7-1.6 \%$ \\
\hline & & Osimertinib [46] & $\begin{array}{l}\text { EGFR-mutated advanced NSCLC } \\
\text { EGFR-T790M-mutated advanced NSCLC }\end{array}$ & $4 \%$ \\
\hline & \multirow{5}{*}{ ALK inhibitors } & Crizotinib [47-49] & ALK- and ROS-1-positive advanced NSCLC & $1.2-1.8 \%$ \\
\hline & & Ceritinib [47] & ALK-positive advanced NSCLC & $1.1 \%$ \\
\hline & & Alectinib [47] & ALK-positive advanced NSCLC & $2.6 \%$ \\
\hline & & Lorlatinib [47] & ALK positive advanced NSCLC & $1.8 \%$ \\
\hline & & Brigatinib [50,51] & ALK-positive advanced NSCLC & $4.5-7 \%$ \\
\hline & \multirow[b]{2}{*}{ HER2 inhibitors } & Lapatinib [52] & $\begin{array}{l}\text { HER2-positive advanced BC } \\
\text { (+Capecitabine/Trastuzumb/AI) }\end{array}$ & $0.2 \%$ \\
\hline & & Tucatinib [53] & $\begin{array}{l}\text { HER2-positive advanced BC } \\
\text { (+Capecitabine + Trastuzumab) }\end{array}$ & $1.2 \%$ \\
\hline & \multirow{4}{*}{$\begin{array}{l}\text { Multikinase and } \\
\text { angiogenesis inhibitors }\end{array}$} & Sorafenib [55] & $\begin{array}{c}\text { Advanced HCC } \\
\text { Advanced RCC } \\
\text { Advanced differentiated thyroid carcinoma }\end{array}$ & Rare \\
\hline & & Sunitinib [56] & $\begin{array}{c}\text { Advanced GIST } \\
\text { Advanced RCC } \\
\text { Advanced pancreatic NET }\end{array}$ & Rare \\
\hline & & Pazopanib [57] & $\begin{array}{c}\text { Advanced RCC } \\
\text { Selective subtypes of advanced STS }\end{array}$ & Rare \\
\hline & & Imatinib [58] & $\begin{array}{l}\text { Kit-positive GIST, advanced and adjuvant setting } \\
\text { Advanced dermatofibrosarcoma protuberans }\end{array}$ & Rare \\
\hline & \multirow[b]{2}{*}{ BRAF and MEK Inh. } & Trametinib [59] & V600 BRAF-mutated advanced melanoma & $2.4 \%$ \\
\hline & & Trametinib + Dabrafenib $[60,61]$ & V600 BRAF-mutated advanced melanoma & $\leq 1 \%$ \\
\hline & PI3K Inh. & Alpelisib [62] & $\begin{array}{l}\text { HR-positive HER2-negative advanced BC with a PIK3CA } \\
\text { mutation, plus fulvestrant, second line }\end{array}$ & $0.7-1.8 \%$ \\
\hline
\end{tabular}


Table 2. Cont.

\begin{tabular}{|c|c|c|c|c|}
\hline Class & Drug & \multicolumn{2}{|c|}{ Use } & $\begin{array}{l}\text { Incidence of Lung Toxicity } \\
(\%), \text { Any Grade * }\end{array}$ \\
\hline \multirow{5}{*}{ mTORs inhibitors } & \multirow{4}{*}{ Everolimus [63-66] } & \multicolumn{2}{|c|}{ HR-positive advanced BC } & $12-38 \%$ \\
\hline & & \multicolumn{2}{|c|}{ Advanced RCC } & $14 \%$ \\
\hline & & \multicolumn{2}{|c|}{ Advanced NET } & $12 \%$ \\
\hline & & \multicolumn{2}{|c|}{ Advanced pancreatic NET } & $17 \%$ \\
\hline & Temsirolimus $[63,67,68]$ & \multicolumn{2}{|c|}{ Advanced RCC } & $2-22 \%$ \\
\hline \multirow{6}{*}{ Monoclonal antibodies } & \multirow{2}{*}{ HER2 inhibitors } & Trastuzumab [69-71] & HER2-positive BC & $0.6 \%$ \\
\hline & & Pertuzumab [72] & HER2-positive BC & $<1 \%$ \\
\hline & \multirow[t]{2}{*}{ EGFR inhibitors } & Cetuximab $[73,74]$ & $\begin{array}{l}\text { RAS wt advanced CRC } \\
\text { Advanced squamous } \\
\text { HN cancer }\end{array}$ & $1 \%$ \\
\hline & & Panitumumab [75] & RAS wt advanced CRC & Case report \\
\hline & VEGF inhibitors & Bevacizumab [76] & $\begin{array}{c}\text { Advanced CRC } \\
\text { Advanced BC } \\
\text { Advanced NSCLC } \\
\text { Advanced RCC } \\
\text { Advanced ovarian cancer } \\
\text { Advanced uterine } \\
\text { cervix cancer }\end{array}$ & Case report \\
\hline & VEGFR2 inhibitors & Ramucirumab [77-79] & $\begin{array}{l}\text { Advanced gastric and } \\
\text { gastro-oesophageal cancer } \\
\text { (alone or with paclitaxel) }\end{array}$ & $\begin{array}{l}\text { 1.5\% plus paclitaxe } \\
10.4 \% \text { alone }\end{array}$ \\
\hline \multirow{4}{*}{ ADC } & \multicolumn{2}{|c|}{ Trastuzumab emtansine [80] } & HER2-positive BC & $9 \%$ \\
\hline & \multicolumn{2}{|c|}{ Enfortumab vedotin [81] } & Advanced urothelial cancer & $<1 \%$ \\
\hline & \multicolumn{2}{|c|}{ Sacituzumab govitecan [82] } & $\begin{array}{c}\text { Triple-negative } \\
\text { advanced BC }\end{array}$ & Unknown \\
\hline & \multicolumn{2}{|c|}{ Trastuzumab deruxtecan $[83,84]$} & HER2-positive BC & $13.6-17.4 \%$ \\
\hline
\end{tabular}

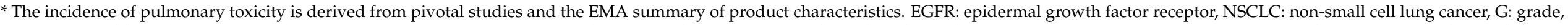

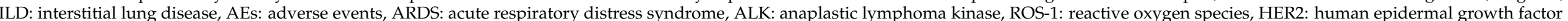

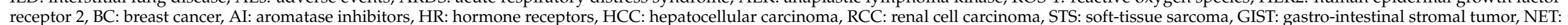
neuroendocrine tumor, CRC: colorectal cancer, HN: head and neck cancer, wt: wild type, VEGF: vascular endothelial growth factor, ADC: Antibody-drug conjugate. 


\subsection{Tyrosine Kinases Inhibitors}

Tyrosine kinase inhibitors (TKIs) are small molecules that inhibit the activation of protein kinases that, by means of protein phosphorylation, are involved in the activation mechanisms of proteins involved in cell growth processes. These proteins are often hyperexpressed or hyperactivated in some forms of cancer, making these drugs a very important therapeutic weapon in the treatment of solid tumors. Table 2 presents the TKIs for which cases of drug-related interstitial pneumonia were reported in the technical data sheet and registration studies.

The underlying mechanism of pulmonary toxicity can be different from one molecule to another. However, the mechanism is not completely known and partly depends on the mechanism of action of the drug itself. For example, it was postulated that interstitial lung disease caused by gefitinib, an EGFR inhibitor used in the treatment of EGFR-mutated nonsquamous NSCLC, is most likely related to a decrease in alveolar regeneration, a process normally regulated by EGFR, in a population with a high co-incidence of lung disease [44]. In a meta-analysis conducted to define the different toxicity profiles of EGFR TKI, erlotinib, gefitinib and afatinib, toxicity-related deaths were rare $(1.7 \%)$, with pneumonitis being the most frequent cause and no significant difference between the different drugs [44]. Another meta-analysis conducted to evaluate the risk of ILD associated with the use of EGFR-TKIs, gefitinib, erlotinib and afatinib, concluded that the incidences of all-grade and high-grade ILD were $1.6 \%$ and $0.9 \%$, respectively. Again, no significant difference in ILD risk was found in the subgroup analysis by EGFR-TKI drugs [45]. For osimertinib, the latest generation of anti-EGFR TKIs, in the pivotal study FLAURA, $4 \%$ of patients in the osimertinib arm developed interstitial lung disease compared to $2 \%$ of patients in the standard EGFR-TKI arm (gefitinib or erlotinib) [46].

ALK inhibitors, either first (crizotinib), second (alectinib, ceritinib, brigatinib) or third generation (lorlatinib), can also lead to lung interstitial toxicity. Several hypotheses have been suggested to better clarify the mechanisms responsible for pulmonary toxicity exerted by ALK-TKIs with particular regard to crizotinib, but they all derive from case reports and retrospective studies [51]. In a systematic review conducted by Pellegrino and colleagues, pulmonary adverse events attributed to crizotinib occurred in $1.8 \%$ of cases, $1.1 \%$ attributed to ceritinib, $2.6 \%$ to alectinib, $1.8 \%$ to lorlatinib and $7 \%$ to brigatinib, which was therefore identified as the ALK inhibitor with the highest percentage of ILD [47]. Across all studies of brigatinib, at a starting dose of $90 \mathrm{mg}$ once daily, $4.5 \%$ of patients experienced any grade event of pneumonitis with a median time to onset of 2 days. Three percent of patients had grade 3 or higher events that led to drug discontinuation [48,51]. In a recent study by Hwang et al. in patients with NSCLC treated with ALKs, COP was the most common pattern ( $64 \%$ of the sample), followed by HP and AIP. All patients with COP were successfully cured, whereas half of them with AIP died [85].

ILD during treatment with anti-HER2 tyrosine kinase inhibitors is rarely reported in the literature. Four studies totaling 4470 patients who received lapatinib were reported in a recently published review, eight of whom $(0.2 \%)$ had at least one reported ILD event [52]. Tucatinib is a highly selective oral tyrosine kinase inhibitor for the kinase domain of HER2, with minimal inhibition of the epidermal growth factor receptor. In the pivotal study, Her2climb, a percentage of $1.2 \%$ of patients in the tucatinib arm reported ILD [53]. Several antiangiogenic TKIs with different binding capacities to angiogenic kinases are used in clinical practice: sorafenib, sunitinib, pazopanib, regorafenib, cabozantinib, nintedanib and axitinib. It is important to remember that these molecules act not only on vascular endothelial growth factor receptor (VEGFR) but also on multiple kinase receptors. For example, cabozantinib is a multi-kinase inhibitor of VEGFR-1, -2 and -3, KIT, TRKB, FLT-3, AXL, RET, MET and TIE -2, and regorafenib exhibits a broad spectrum of activity with inhibition of tyrosine kinases involved in tumor angiogenesis mechanisms (e.g., PDGFR, FGFRs 1-2, VEGFRs 1-3, TIE2), proliferation (RET, RAF, KIT), tumor microenvironment and metastasis processes (VEGFR2-3, PDGFR). 
When used alone, adverse pulmonary events are rare and mostly described in case reports. ILD is more common when a multi-kinase inhibitor also inhibits platelet-derived growth factor receptor (PDGFR). A PDGFR $\alpha$ and PDGFR $\beta$ inhibitor associated with ILD, although rarely, is imatinib [58]. A possible mechanism of lung injury could be related to PDGFR inhibition. Imatinib-induced ILD is likely to develop in more susceptible patients, such as those with a history of pneumonia. However, ILD occurs less frequently with VEGFR and PDGFR-TKIs than with EGFR-TKIs. Sorafenib in particular has rarely been associated with cryptogenic organizing pneumonia (COP) and non-specific interstitial pneumonia (NSIP) patterns [55].

Another class of TKIs with great clinical relevance in oncological treatments, especially melanoma, non-small-cell lung cancer (NSCLC) and, recently, colorectal cancers, is BRAF and MEK tyrosine kinase receptor inhibitors. Respiratory complications are extremely rare with BRAF inhibitor monotherapy, such as vemurafenib or dabrafenib. Regarding mek-inhibitors (MEKi), in the pivotal trametinib + dabrafenib doublet study conducted by Flaherty and colleagues [59], interstitial pneumonia occurred in $2.4 \%$ of patients treated with trametinib alone, and all patients who presented this adverse event required hospitalization. The median time to first presentation was 160 days (range 60-172 days). Therefore, in all patients treated with trametinib who present with cough or suspicious symptoms and signs of pneumonitis, radiological examinations and temporarily suspended treatment should be investigated [59].

\section{2. $m T O R$}

Regarding mTOR inhibitor (mTORi) drugs, ILD is a widely described and studied adverse event with high relevance and incidence in clinical practice. Although the majority of patients with mTORi-related ILD are asymptomatic or mildly symptomatic, it is important not to underestimate this clinical finding and to adhere to the recommendation regarding the management of this toxicity, as in some cases, it can lead to important respiratory outcomes. All mTORi drugs can be related to this adverse event; however, among them, the pulmonary toxicity profile appears to differ. A retrospective analysis of 196 patients revealed a higher incidence of ILD in patients receiving everolimus than in those receiving temsirolimus ( $38 \%$ vs. $22 \%, p=0.018$ ) [63]. The reported incidence of mTORi pulmonary toxicity in the literature differs from that of clinical studies, probably due to a greater awareness of this adverse event and greater precision in radiological diagnostic criteria. The first phase 2 clinical trials with everolimus and temsirolimus reported incidences of clinically manifest ILD of 3-13\%. Real-life studies report an incidence of ILD that ranges from $14 \%$ to $45 \%$ for temsirolimus and from $3 \%$ to $54 \%$ for everolimus $[86,87]$. Regarding the mechanisms of lung damage, unlike bleomycin, a dose-dependent correlation is not evident [67]. The pathophysiological mechanisms of mTORi-mediated lung injury are complex. Preclinical studies have described direct damage to the endothelium and epithelium, depletion of alveolar macrophages and accumulation of surfactant lipids. Both epithelial and endothelial damage with accumulation of surfactant contribute to a pulmonary inflammatory state. Furthermore, mTORi-mediated epithelial damage could expose cryptic antigens, activating a T-mediated immune response, resulting in lymphocytic alveolitis and interstitial pneumonia [88]. It is also possible that the mTORi molecule leads to a delayed-type hypersensitivity reaction. Indeed, mTORi has a high affinity for plasma proteins, and the resulting mTORi-protein complex can be immunogenic, processed by antigen-presenting cells and recognized by $\mathrm{T}$ cells. This process leads to cytokine release and preferential differentiation of Th0 cells into Th1 cells with recruitment and activation of macrophages and other inflammatory cells. Finally, several preclinical studies have demonstrated how mTOR inhibitors interfere with the pathways of damage and repair of lung tissue by inducing a sustained inflammatory response through the downregulation of the phosphatidylinositol-3-kinase (PI3K) pathway and the consequent production of pro-cytokines, such as interleukin (IL)-12, IL-23, tumor necrosis factor (TNF) and IL$1 \beta$ [89]. Again, clinically, the symptoms and signs are nonspecific. The time to onset of 
ILD after initiation of treatment is relatively short, mostly occurring within 6 months after starting treatment.

A diagnosis of noninfectious pneumonitis should be considered in patients presenting with nonspecific respiratory signs and symptoms, such as cough, dyspnoea, hypoxia, fever and fatigue, and in whom infectious, neoplastic and other nonmedicinal causes have been excluded by means of appropriate investigations. Patients who develop radiological changes and have few or no symptoms may continue everolimus without dose adjustments (Grade 1). If symptoms are moderate (Grade 2) or severe (Grade 3), the drug should be discontinued, and the use of corticosteroids (such as oral prednisone $0.75-1.0 \mathrm{mg} / \mathrm{kg}$ or in severe cases, intravenous methylprednisolone) may be indicated until clinical symptoms resolve. Given the immunosuppressive properties of everolimus, the use of corticosteroids and possible respiratory distress, the coadministration of broad-spectrum antibiotics may also be considered for Grade 3 or 4. Opportunistic infections should also be considered; indeed, prophylaxis for Pneumocystis jirovecii (carinii) pneumonia is recommended [90].

Generally, in mTOR inhibitor pneumonitis, pulmonary function tests are associated with a restrictive pattern or an isolated reduction in diffusing capacity [91]. The most characteristic radiological changes include ground-glass and reticular opacities, in particular of the lower lobes of the lungs. mTOR inhibitor-associated pneumonitis most commonly presents as either cryptogenic organizing pneumonia (COP) or nonspecific interstitial pneumonia (NSIP) [92,93].

Some evidence suggests that everolimus-related pneumonia is associated with improved prognosis and may be used as a biomarker for the efficacy of the drug, especially in breast cancer [94].

\subsection{Phosphatidylinositol 3-Kinase (PI3K) Inhibitors}

Activation of the PI3K signaling pathway is frequently associated with tumorigenesis. Moreover, dysregulated PI3K signaling may contribute to tumor resistance to a variety of cancer drugs. Several molecules that act on the Pi3k-AKT signaling pathway are being studied. A PIK3 inhibitor approved by the FDA and EMA for the treatment of solid tumors is alpelisib. This new molecule has recently entered clinical practice, and the possible range of side effects is not completely known. Pneumonitis occurred in $1.8 \%$ of patients receiving alpelisib in the pivotal SOLAR-1 study [62]. Specific monitoring guidelines have been established to address this side effect. In particular, permanent discontinuation of alpelisib is advised in any patient who develops pneumonitis [95].

\subsection{Monoclonal Antibodies}

Monoclonal antibodies used in clinical practice in the treatment of solid tumors are monoclonal antibodies against Her family receptors, such as panitumumab, cetuximab and trastuzumab, and monoclonal antibodies that target vascular endothelial growth factor (VEGF), such as bevacizumab, or its receptor, such as ramucirumab.

For monoclonal antibodies targeting Her family receptors, panitumumab and cetuximab bind directly to EGFR, whereas trastuzumab and pertuzumab bind to the HER2 protein expressed on the cell surface, inhibiting the EGFR pathway. Unlike tyrosine kinase inhibitors acting on EGFR, for which ILD is a widely described adverse event, its incidence is not known for monoclonal antibodies, and reports of this event are very rare. In pivotal studies of panitumumab and cetuximab, interstitial pneumonia was not a reported event. Regarding trastuzumab, in a pivotal study in the adjuvant setting, the rate of interstitial pneumonitis was $0.6 \%$ [71]. COP is the prevailing high resolution computed tomography (HRCT) pattern [96]. A review of the literature conducted with the aim of determining the incidence of ILD in patients undergoing anti-HER treatments showed 162 cases $(9.9 \%)$ of drug-related ILD. Overall, there were $3(0.2 \%)$ ILD-related deaths among those receiving trastuzumab therapy [55]. In the EMA datasheet for pertuzumab, ILD is reported as a rare event; to our knowledge, there are no case reports for pertuzumab concerning this topic. In the CLEOPATRA combination study of docetaxel, pertuzumab and trastuzumab in the 
metastatic first-line Her2+ breast cancer, no significant rates of pneumonia were reported compared to the docetaxel and trastuzumab placebo arms, which occurred in a very low percentage of patients [72].

For monoclonal antibodies targeting VEGF or its receptor (VEGFR), interstitial pneumonitis is a very rare event and mostly reported as case reports. A study on bevacizumab, a monoclonal antibody directed at VEGF, hypothesized a protective role of bevacizumab on interstitial pulmonary toxicity mediated by chemotherapy; however, there are no data in the literature to support this hypothesis [76]. Ramucirumab is a VEGFR-2 inhibitor. In the phase 3 RAINBOW pivotal trial of ramucirumab in combination with paclitaxel in secondline treatment of advanced gastric cancer, the incidence of treatment-related pneumonitis was lower in patients who received the combination treatment $(1.5 \%)$ than in those who received paclitaxel alone (2.1\%) [77]. In the REGARD study of ramucirumab monotherapy in pretreated advanced gastric cancer, ramucirumab-related pneumonia occurred in $0.4 \%$ of patients [78]. In a retrospective study of 44 gastric cancer patients who received combination treatment with ramucirumab and paclitaxel, six patients (13.6\%) developed pneumonitis during the first five cycles of treatment. The onset of pneumonitis was independently associated with the presence of pre-existing $\operatorname{ILD}(p=0.025$; odds ratio $=206.4)$ [79].

\subsection{Antibody-Drug Conjugates (ADCs)}

Antibody-drug conjugates (ADCs) are complex molecules composed of a monoclonal antibody bound to a biologically active cytotoxic drug, thus combining the ability to "target" specific molecules, typical of monoclonal antibodies, with the cytotoxic properties of chemotherapy drugs. Among the ADCs are trastuzumab emtansine and a series of new drugs recently approved by the FDA but still under approval in Europe for the treatment of solid tumors, namely, enfortumab vedotin, trastuzumab deruxtecan and sacituzumab govitecan. The pulmonary toxicity profile is very different for this class of drugs.

Trastuzumab emtansine (T-DM1) is an ADC that combines the monoclonal antibody trastuzumab with cytotoxic mertansin (DM1), a maytansinoid class anti-microtubule agent bound by a stable thioether. T-DM1 binds to the HER2 receptor, and the HER2 and TDM1 complex enters target cells through receptor-mediated endocytosis. This process leads to the intracellular release of DM1, favoring its cytotoxic activity. In addition, the drug retains its anti-HER2 properties, including inhibition of HER2 intracellular signaling pathways and induction of cell-mediated cytotoxicity. Cases of ILD have been reported in patients receiving T-DM1. Pneumonitis of any grade shows an incidence rate up to $9 \%$, whereas severe pneumonitis (grade $\geq 3$ ) was recorded in $1-6 \%$ of all patients treated with T-DM1 [80].

Enfortumab vedotin is a human IgG1 antibody directed against nectin-4, an adhesion protein located on the cell surface. The small molecule MMAE is an antimitotic agent that interferes with the formation of microtubules attached to the antibody via a clearable linker with protease. Additionally, in this case, internalization through the ligand allows the cytotoxic activity of the drug. In a pivotal study of enfortumab vedotin in urothelial carcinoma after treatment with platinum and immunotherapy, one treatment-related death from ILD was reported [81].

Sacituzumab govitecan is an anti-Trop-2 antibody conjugated with SN-38 Trop-2, an active metabolite of irinotecan. Irinotecan is a chemotherapeutic agent that has been associated with cases of interstitial pneumonia, so it is plausible that sacituzumab govitecan may present this toxicity as well. However, in the phase 1-2 study of sacituzumab govitecan in patients with metastatic triple-negative breast cancer, no cases of ILD were observed among the 108 patients enrolled. Among the 5 patients ( $5 \%$ of total) who experienced Grade 3 or 4 adverse respiratory events, none of the events were considered by the investigators to be related to sacituzumab govitecan. More data will certainly be needed to understand whether the drug may present such toxicity [82].

Trastuzumab deruxtecan is an ADC where the antibody directed against HER-2 is conjugated to a topoisomerase inhibitor. In the single-arm study DESTINY-Breast01, ILD 
was reported in $13.6 \%$ of patients receiving trastuzumab deruxtecan, leading to death in $2.2 \%$ of patients $[83,84]$. Numerous ongoing trials are evaluating trastuzumab deruxtecan in the treatment of different tumor histotypes. Certainly, the problem of pulmonary toxicity will be of extreme importance in the near future, in which the rapidly increasing therapeutic scenario sees these drugs as the main leading actor in the target treatment across tumor types.

\section{Immunotherapy and Lung Toxicity}

Immunotherapy treatment has become the standard of care in the metastatic setting in several neoplastic diseases. Since the first immunotherapy studies, the problem of interstitial pulmonary toxicity has been highlighted as an important side effect to be taken into consideration. ILD resulting from immunotherapy drugs recognizes a clear pathophysiological mechanism linked to the activity of the drug itself.

Programmed death-1 (PD1), the PD-1 ligand (PDL1) and the cytotoxic T-4 lymphocyteassociated antigen (CTLA4) are called immune checkpoint molecules because they negatively regulate host immunity. This ability to evade immune surveillance is part of the tumor skipping and disease growth process. Immune checkpoint inhibitors are antibodies that inhibit PD-1, PD-L1 or CTLA-4, resulting in activation of the immune response. The toxicity profile of immunotherapy drugs differs from that of cytotoxic drugs and is characterized by peculiar adverse events, known as immune-related adverse events (irAEs) [97]. Immune-mediated interstitial pneumonia is rarer than other irAEs but more severe [98].

The incidence of this toxicity is higher in patients undergoing immunotherapy treatment for lung cancer than in other tumor types reported for targeted therapies is higher in patients with a history of previous pulmonary diseases [99]. It is important to emphasize that combination therapies with anti-PD-1 and anti-CTLA4 antibodies show a higher incidence of ILD than monotherapy. To date, no identifiable risk factors for ILD are known that could be considered to prevent its onset. A single-center retrospective study conducted by Okada and colleagues among 102 patients treated for lung cancer diagnosed with ILD concluded that ECOG PS (Performance Status according to Eastern Cooperative Oncology Group) $\geq 2$ alone or the presence of both ECOG PS $\geq 2$ and a history of smoking with $\geq 50$ pack-years acted as risk factors for Grade $\geq 3$ and all grades of ILD, respectively [100]. In descending order of toxicity, the most reported patterns are AIP (high grade), COP (intermediate grade) and finally, NSIP and HP (low grade) [101].

Several literature reports propose the onset of irAEs, such as interstitial pneumonitis, as a predictor of response to immunotherapeutic drugs, but this assumption is not currently considered certain [102]. Table 3 reports the immunotherapy drugs currently used in clinical practice classified by the mechanism of action (anti-PD1, anti-PDL1 and anti-CTLA4), their indication in the various neoplastic pathologies and the relative incidence of interstitial pneumonitis reported in pivotal studies. 
Table 3. Incidence of pneumonitis with immune checkpoint inhibitors approved by the FDA and EMA in the treatment of solid tumors.

\begin{tabular}{|c|c|c|}
\hline Drug & Indications & $\begin{array}{l}\text { \% of Pneumonitis } \\
\text { (Including ILD), Any Grade }\end{array}$ \\
\hline \multirow{7}{*}{$\begin{array}{l}\text { Nivolumab } \\
\text { monotherapy [103-109] }\end{array}$} & Metastatic melanoma & $1.5 \%$ \\
\hline & Adjuvant melanoma & $1.3 \%$ \\
\hline & Squamous NSCLC second line & $5 \%$ \\
\hline & Non squamous NSCLC second line & $3 \%$ \\
\hline & HNSCC second line & $2.1 \%$ \\
\hline & RCC second line & $4 \%$ \\
\hline & Metastatic urothelial carcinoma after platinum cht & $3 \%$ \\
\hline \multirow{2}{*}{ Nivolumab + ipilimumab $[110,111]$} & Metastatic melanoma & $6.4 \%$ \\
\hline & RCC first line for intermediate-high risk & $6.2 \%$ \\
\hline \multirow{8}{*}{$\begin{array}{l}\text { Pembrolizumab } \\
\text { monotherapy [112-119] }\end{array}$} & HNSCC first line, PD-L1 positive with a CPS $\geq 1$ & $6 \%$ \\
\hline & HNSCC second line & $4 \%$ \\
\hline & NSCLC first line, PDL1 $\geq 50 \%$ & $2.6 \%$ \\
\hline & NSCLC second line, PDL1 $\geq 1 \%$ & $5 \%$ \\
\hline & Metastatic melanoma & $1.8 \%$ \\
\hline & Adjuvant stage III melanoma & $3.3 \%$ \\
\hline & $\begin{array}{l}\text { Locally advanced/metastatic urothelial carcinoma } \\
\text { second line }\end{array}$ & $4.1 \%$ \\
\hline & $\begin{array}{l}\text { Locally advanced/metastatic urothelial carcinoma } \\
\text { in adults not eligible for cisplatin-containing cht, } \\
\text { PD-L1 positive and CPS } \geq 10\end{array}$ & $2 \%$ \\
\hline \multirow{3}{*}{$\begin{array}{c}\text { Pembrolizumab }+ \\
\text { chemotherapy }[112,120,121]\end{array}$} & $\begin{array}{l}\text { NCSLC first line in combination with carboplatin + } \\
\text { pemetrexed }\end{array}$ & $4.4 \%$ \\
\hline & $\begin{array}{l}\text { NCSLC first line in combination with carboplatin + } \\
\text { paclitaxel/nab-paclitaxel }\end{array}$ & $6.5 \%$ \\
\hline & $\begin{array}{l}\text { HNSCC first line in combination with platinum } \\
\text { and 5-fluorouracil, PD-L1 positive and CPS } \geq 1\end{array}$ & $5 \%$ \\
\hline $\begin{array}{l}\text { Pembrolizumab } \\
+ \text { axitinib [122] }\end{array}$ & RCC first line & $2.8 \%$ \\
\hline \multirow[t]{2}{*}{$\begin{array}{l}\text { Atezolizumab } \\
\text { monotherapy }[123,124]\end{array}$} & $\begin{array}{l}\text { Locally advanced/metastatic urothelial carcinoma } \\
\text { second line }\end{array}$ & $2 \%$ \\
\hline & NSCLC second line & $1 \%$ \\
\hline $\begin{array}{c}\text { Atezolizumab } \\
+ \text { nab-paclitaxel [125] }\end{array}$ & Advanced TNBC first line & $3.1 \%$ \\
\hline $\begin{array}{l}\text { Durvalumab } \\
\text { monotherapy [126] }\end{array}$ & $\begin{array}{c}\text { Locally advanced unresectable NSCLC, } \\
\text { PD-L1 } \geq 1 \% \text {, not progressed following platinum } \\
\text { based cht }\end{array}$ & $12.6 \%$ \\
\hline Durvalumab + platinum-etoposide [127] & Extensive-stage SCLC first line & $3 \%$ \\
\hline $\begin{array}{l}\text { Avelumab } \\
\text { monotherapy [128] }\end{array}$ & Metastatic Merkel cell carcinoma & $1 \%$ \\
\hline Avelumab + axitinib [129] & Advanced RCC first line & $0.6 \%$ \\
\hline Ipilimumab monotherapy $[130,131]$ & Advanced melanoma & $2 \%$ \\
\hline
\end{tabular}

ILD: interstitial lung disease; NSCLC: non-small cell lung cancer; HNSCC: head and neck squamous cell carcinoma; RCC: renal cell carcinoma; CHT: chemotherapy; CPS: combined positive score; TNBC: triple-negative breast cancer; SCLC: small cell lung cancer. 


\subsection{Anti-PD1}

PD-1 is a member of the immunoglobulin superfamily that can be detected on activated T cells, B cells and natural killer (NK) cells, and binds PDL-1 and PDL-2. PD-L1, expressed by tumor cells and immune cells, also interacts with CD80, whereas PD-L2, expressed only on dendritic cells in normal tissue, interacts with RGMb (repulsive guide molecule B). All these interactions mediate an inhibitory signal that leads to the suppression of $\mathrm{T}$ cell activation. Anti-PD1-related lung toxicity, including ILD, recognizes autoimmune genesis following activation of T cells. Patients treated with PD1 antibodies should be monitored for signs and symptoms of pneumonia, clinical suspicion should be confirmed with radiographic images and other potential causes must be excluded [132]. In cases of Grade $\geq 2$ pneumonia, immunotherapy is temporarily suspended, and steroid treatment is administered with an initial dose equivalent to $1-2 \mathrm{mg} / \mathrm{kg} /$ day prednisone. Instead, treatment should be permanently discontinued for Grade 3, Grade 4, or Grade 2 recurrent pneumonia. The anti-PD-1 monoclonal antibodies approved by the FDA and EMA for the treatment of solid tumors include nivolumab and pembrolizumab.

The incidence of pneumonia in pivotal studies of nivolumab monotherapy ranges from $1.3 \%$ to $5 \%$ and is higher in patients with NSCLC $[107,108]$. Regarding the combination of nivolumab with ipilimumab, an anti-CTLA4, in melanoma, the incidence of pneumonia was $6.4 \%$ [110]; however, in RCC, the incidence was 6.2\% [111]. Pembrolizumab is an anti-PD 1 approved for the treatment of solid tumors both alone and in combination with chemotherapy. Keynote 426 enabled the registration of pembrolizumab in combination with axitinib as the first-line renal cell carcinoma treatment. In the pembrolizumab studies in NSCLC, the rate of interstitial pneumonia was higher than in the other studies, especially in patients with a history of chest radiation therapy (see Table 3).

\subsection{Anti-PDL1}

Another class of immune checkpoint inhibitors are monoclonal antibodies that inhibit PDL-1. As mentioned, activation of PD-1/PD-L1 signaling negatively regulates T cellmediated immune responses in peripheral tissues. Through antibody-mediated PD-L1 inhibition, the immunosuppressive signals present in the tumor microenvironment are reduced with a consequent increase in T cell-mediated immunity against tumors [133]. Currently, there are three FDA- and EMA-approved PD-L1 inhibitors for the treatment of various malignancies, namely, atezolizumab, durvalumab and avelumab. Table 3 shows their current indications in clinical practice and the percentage of pneumonia reported in pivotal studies.

Special mention should be made of the Pacific study, which led to the approval of durvalumab in locally advanced, unresectable non-small cell lung cancer patients with PD-L1 expression $\geq 1 \%$ whose disease did not progress after platinum-based chemoradiotherapy [126]. As also reported for other oncological drugs, including chemotherapy, biology and immunotherapy, the percentage of interstitial pneumonia is higher in patients undergoing radiotherapy on the chest $[134,135]$. Therefore, a careful clinical evaluation of patient candidates to receive durvalumab in this setting is strongly recommended.

\subsection{Anti-CTLA4}

CTLA-4 is a coinhibitory molecule and is the counterpart of the costimulatory B7CD28 axis. Upon activation, $\mathrm{T}$ lymphocytes positively regulate the surface expression of CTLA-4, which binds B7 with increased avidity and thereby overcomes the positive costimulatory signal of CD28. This dominance of negative signals results in a reduced proliferation of T cells and a decrease in the production of IL-2. The blockade of CTLA-4, and therefore the release of B7 for the interaction with the costimulatory molecule CD28, activates the immune response [136].

Anti-CTLA4 monoclonal antibodies exhibit a higher rate of immune-related adverse events, including pneumonitis, compared with anti-PD1 and anti-PDL1 drugs. In the CheckMate 238 study, which randomized patients to receive nivolumab or ipilimumab as 
adjuvant treatment in resected stage III or IV melanoma, pneumonia occurred in $1.3 \%$ of cases in the nivolumab arm and in $2.4 \%$ in the ipilimumab arm [104]. The mechanisms underlying the higher rate of immune-related side effects from anti-CTLA-4 drugs remain unclear. Currently, their use as monotherapy in clinical practice remains confined to melanoma [130].

\section{Diagnosis and Therapy}

Several radiological patterns are used to describe interstitial lung disease (ILD), unfortunately mostly without specificity to differentiate the multitude of potential conditions, which include infections (especially viral), immunological diseases (also allergies), toxicities, idiopathic forms and even possibly mimic tumor progression. Radiology can be useful in grading the severity and guiding therapeutic management. As defined by the American Thoracic Society and the European Respiratory Society (ATS/ERS) in correlation with histological findings, the most common patterns are presented below [137]. It is worth noting that it may occasionally not be possible to identify a case with a specific pattern, and even overlapping among them is possible [138].

AIP (acute interstitial pneumonia) has been historically associated with bleomycin, alkylating agents (such as cyclophosphamide) and antimetabolites (such as methotrexate). Extensive ground-glass opacities and dependent consolidations can be found in a setting that can correspond to ARDS (acute respiratory distress syndrome). Fibrosis may develop within one week, and the prognosis is mainly poor. Corticosteroid therapy is recommended.

NSIP (non-specific interstitial pneumonia) is typically characterized by subtle evolution, distinguishable into cellular and fibrotic types, and is correlated with more indolent and aggressive clinical forms. Ground-glass opacities are the dominant feature, displaying basal predominance with sparing of subpleural spaces. Thickening of bronchovascular bundles with traction bronchiectasis and consequently lung volume loss are the expressions of the advanced stage. Early diagnosis can significantly impact therapeutic and prognostic responses that depend on the extent of fibrosis. Mycophenolate mofetil can improve lung function. Methotrexate and carmustine are among the most common related causative agents.

COP (cryptogenic organizing pneumonia) is commonly defined by patchy migratory consolidations, classically with a "reverse halo appearance" (atoll sign), predominantly with peribronchial and subpleural distribution in the lower lung zones and typically associated with nodules and perilobular fibrosis, describing "arches" (arcade-like sign). COP typically responds well to treatment withdrawal, and corticosteroids are occasionally still required. Bleomycin, methotrexate and cyclophosphamide can provoke this condition.

$\mathrm{HP}$ (hypersensitivity pneumonia) is constituted by small, numerous, round and poorly defined centrilobular nodules, widespread areas of ground-glass opacities and hypoattenuating areas persistent even in expiration due to air-trapping phenomena (classically giving an appearance known as the "head cheese sign"). Chemotherapy withdrawal may be resolutive. Bleomycin and methotrexate are potential etiologies.

In comparison with the contingency COVID-19 pandemic, pneumonia typically presents with bilateral and peripheral ground-glass opacities accompanied by consolidations with typical interlobular septal thickening ("crazy paving" appearance). However, a broad spectrum of possible mimic patterns has been described, particularly including the aforementioned ILDs, especially COP and AIP [139]. See Figure 1.

Since the mechanism of uptake of $18 \mathrm{~F}-$-Fluorodeoxyglucose (18F-FDG) is shared by neoplastic cells and inflammatory cells, false positive results interpreted as of oncological significance are frequently caused by underlying infections instead. Therefore, during several antineoplastic treatments, drug-related pneumonitis of any form may be erroneously interpreted as progressive disease by 18F-FDG PET/CT [140-144]. To date, this represents a hard to solve diagnostic dilemma, at least on the basis of the conventional image qualitative analysis. A possible help in this scenario could come from quantitative imaging, made 
possible from advent of machine learning [145-147]. We provide some examples of ILD images by 18F-FDG PET/CT in Figure 2.
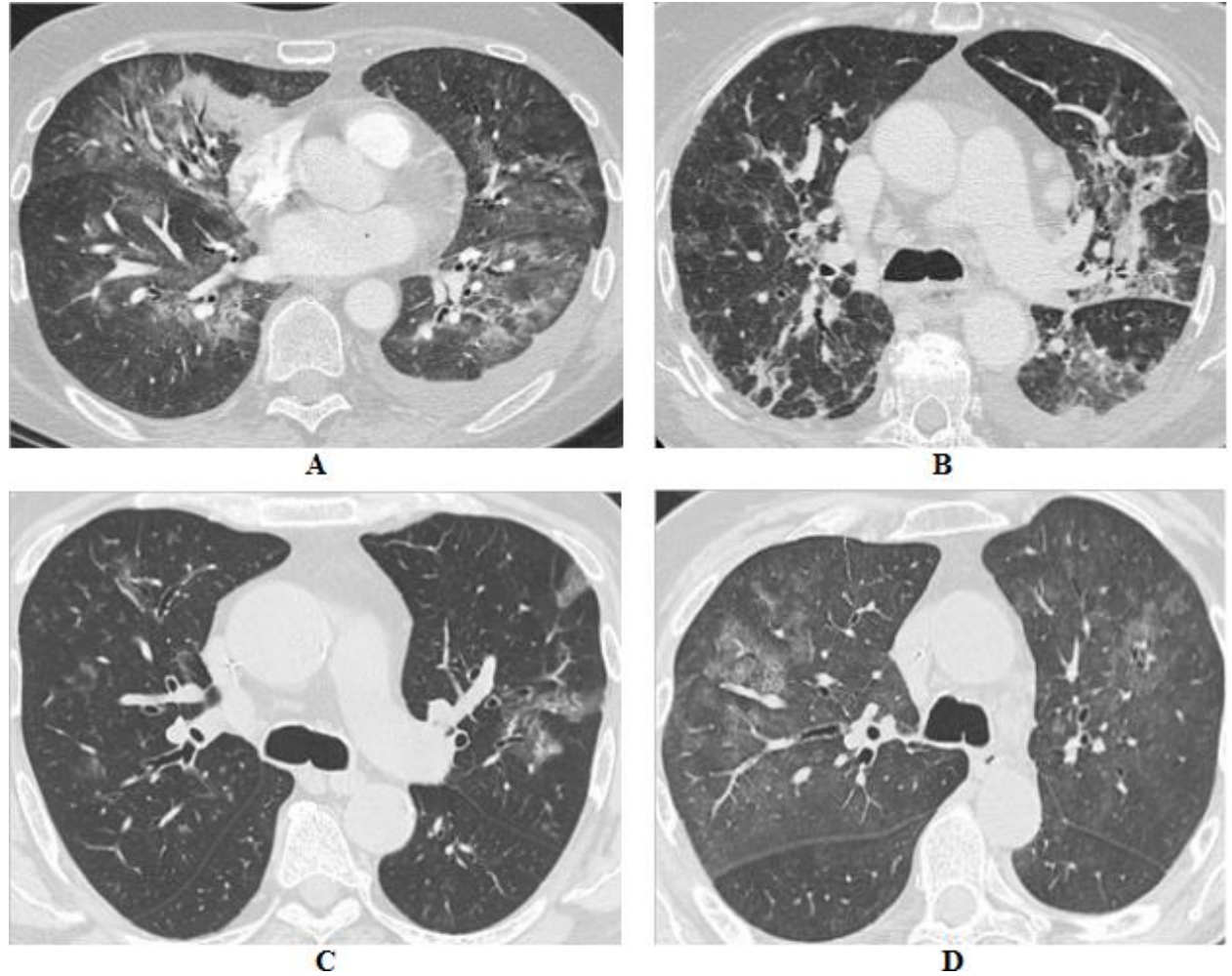

Figure 1. (A) 56-year-old male affected by renal cell carcinoma in treatment with everolimus, (B) 83year-old female affected by esophageal adenocarcinoma in treatment with FOLFOX regimen, (C) 69year-old male affected by gastric adenocarcinoma in treatment with FOLFIRI regimen, (D) 65-year-old female affected by pancreatic adenocarcinoma in treatment with gemcitabine. In (A,B) are shown multifocal consolidations, partly ground glass, in a pattern compatible with COP. In (C,D) scattered and patchy ground-glass opacities with crazy paving appearances, expression of alveolar damage, can be observed. All these patients were hospitalized during the COVID-19 pandemic, nevertheless, despite similar findings for both pairs, only for $(\mathbf{B}, \mathbf{C})$ was SARS-CoV-2 recognized as the causative agent, while for (A,D) chemotherapy was considered the most suspected etiology.

About the clinical presentation, interstitial pneumonitis is often insidious. Dyspnea, dry cough, mild fever and fatigue may be the first clinical symptoms and signs. Differential diagnosis from other causes of pneumonia is essential.

The cornerstone of drug-induced pneumonitis treatment are corticosteroids, since the underlying mechanism of lung damage is the inflammatory and/or the immunological process. In severe cases, with the failure of high-dose steroid therapy, often the evolution to pulmonary fibrosis occurs, which may require other biological or immunosuppressive agents, such as cyclophosphamide, mycophenolate mofetil, azathioprine, infliximab, tocilizumab or rituximab [148,149]. In symptomatic disease, it is important to start treatment as early as possible, in order to achieve a better result.

The management of immunotherapy-related pneumonia, which is the most recently defined ILD, follows a specific guideline [150,151]. For non-immunotherapy related ILDs, if steroid therapy fails, the treatment is based on the therapy of connective tissue diseaserelated ILDs or idiopathic pulmonary fibrosis [149].

The management of drug-related toxicity is based on its severity. Table 4 reports the classification of pneumonia according to severity and Figure 3 summarizes management according to grade, based on the American Society of Clinical Oncology (ASCO) guidelines for the management of immune-related pneumonia [150] (Table 4). 


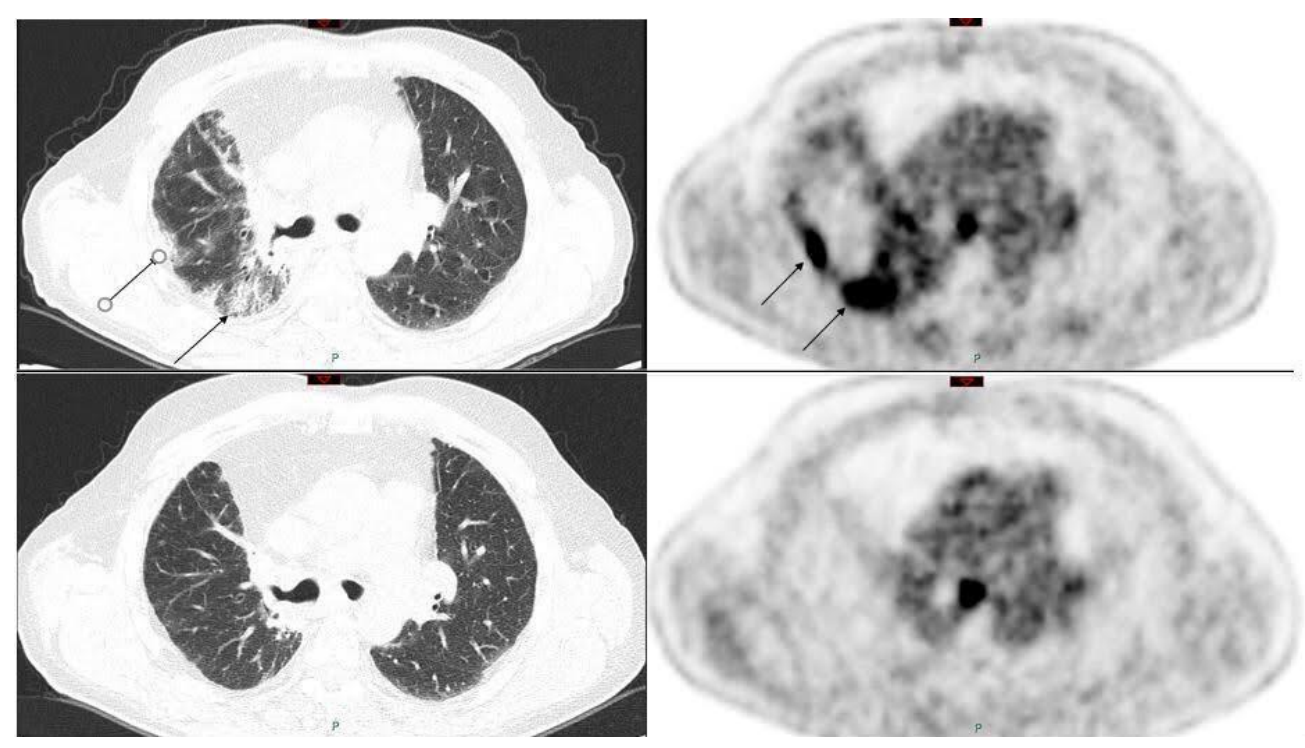

Figure 2. (Upper row): pre-therapy 18F-FDG PET/CT of a patient affected by lung cancer in treatment with atezolimumab, showing some areas of increased uptake of the radiopharmaceutical corresponding to mixed ground-glass and crazy paving lung CT alterations (black arrows). (Lower row): in PET/CT three months later, after atezolimumab suspension, no more areas of uptake are present, therefore indicative of an immune-related pneumonia.

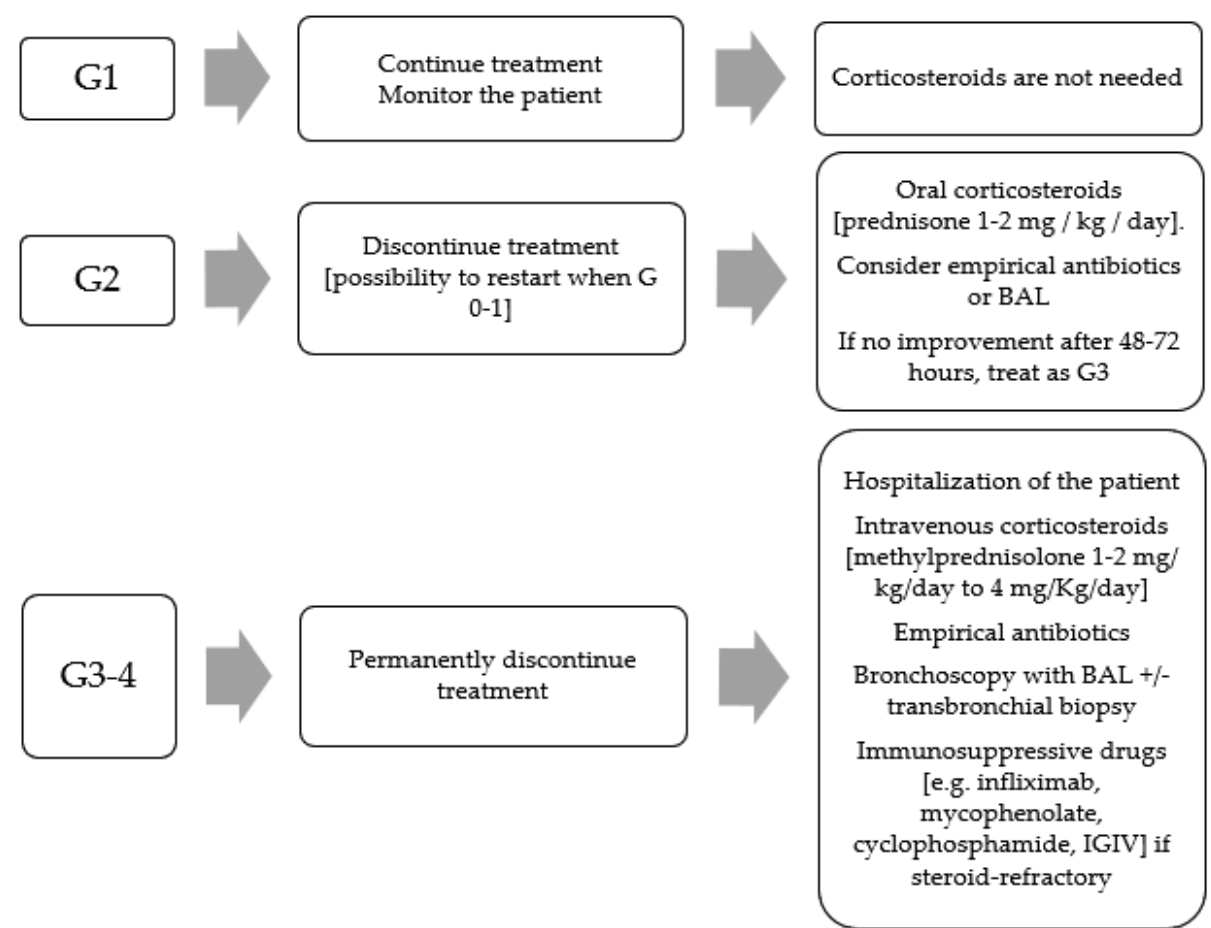

Abbreviations: BAL, bronchoalveolar lavage; IVIG, intravenous immunoglobulin.

Figure 3. Management of pneumonitis according to severity.

It could be identified as an association between the radiographic pattern and the clinical severity of pneumonitis, classifying the different patterns by toxicity grades, where AIP / ARDS pattern had the highest grade, followed by COP pattern, whereas NSIP pattern and HP pattern had lower grade [152]. It appears that NSIP and COP patterns respond better to treatment than UIP patterns [149]. 
Table 4. Pneumonitis severity classification according to NCI-CTCAE version 5.0 and American Society of Clinical Oncology (ASCO) 2018 guidelines.

\begin{tabular}{|c|c|c|c|c|}
\hline Guidelines & G1 & G2 & G3 & G4 \\
\hline CTCAE Version 5.0 & $\begin{array}{l}\text { Asymptomatic, clinical or } \\
\text { diagnostic observations only, } \\
\text { intervention not indicated }\end{array}$ & $\begin{array}{c}\text { Symptomatic, medical } \\
\text { intervention indicated, } \\
\text { limiting instrumental ADL }\end{array}$ & $\begin{array}{c}\text { Severe symptoms, limiting } \\
\text { self-care ADL, } \\
\text { oxygen indicated }\end{array}$ & $\begin{array}{l}\text { Life-threatening } \\
\text { respiratory } \\
\text { Compromise, urgent } \\
\text { intervention indicated } \\
\text { (e.g., tracheotomy } \\
\text { or intubation) }\end{array}$ \\
\hline ASCO guidelines & $\begin{array}{l}\text { Asymptomatic, confined to } \\
\text { one lobe of the lung or }<25 \% \\
\text { of lung parenchyma, clinical } \\
\text { or diagnostic } \\
\text { observations only }\end{array}$ & $\begin{array}{l}\text { Symptomatic, involves more } \\
\text { than one lobe of the lung or } \\
25-50 \% \text { of lung parenchyma, } \\
\text { medical intervention } \\
\text { indicated, limiting } \\
\text { instrumental ADL }\end{array}$ & $\begin{array}{c}\text { Severe symptoms, } \\
\text { hospitalization required, } \\
\text { involves all lung lobes or } \\
>50 \% \text { of lung parenchyma, } \\
\text { limiting self-care } \\
\text { ADL, oxygen indicated }\end{array}$ & $\begin{array}{c}\text { Life-threatening } \\
\text { respiratory compromise, } \\
\text { urgent } \\
\text { Intervention } \\
\text { indicated (intubation) }\end{array}$ \\
\hline
\end{tabular}

Abbreviation: NCI: National Cancer Institute; CTCAE: Common Terminology Criteria for Adverse Events; G: grade; ADL: activity of daily life; Instrumental ADL: activities of daily life such as shopping, preparing food, using the telephone, managing money, etc.

Generally, steroid therapy is recommended for Grade 2 and higher, with oral prednisone $1-2 \mathrm{mg} / \mathrm{kg} /$ day. Grade 3 or 4 requires patient's hospitalization and intravenous (IV) methylprednisolone 1 to $4 \mathrm{mg} / \mathrm{kg} /$ day. Steroid therapy should be continued until the event is resolved or improved to G1 and progressively reduced (e.g., 5-10 mg/week) and then stopped over at least 4-6 weeks, in order to avoid a rebound effect. This is very important in immunotherapy pulmonary toxicities, where, differently from other anticancer agents, it appears that flare pneumonitis can be more severe and extensive than the initial episode. Therefore, the gradual and slow tapering of corticosteroids is essential [152]. In severe cases, if there is no improvement after $48 \mathrm{~h}$ of high-dose steroids, it may be appropriate to add infliximab (an anti-TNF-a immunosuppressive agent) $5 \mathrm{mg} / \mathrm{kg}$ or mycophenolate mofetil $1 \mathrm{~g}$ twice a day or intravenous immunoglobulins (IVIG) $2 \mathrm{~g} / \mathrm{kg} /$ day for 5 days, or cyclophosphamide. In these cases, a pneumological or immunological consultation could be indicated [150].

Patient's immunosuppression (potentially caused by corticosteroids, oncological therapy, cancer, respiratory distress, poor performance status, etc.) requires the simultaneous administration of an empirical antibiotic prophylaxis to avoid superinfections, especially in Grades 3 and 4 (Figure 3).

In the case of prolonged steroid therapy (beyond 12 weeks), prophylaxis for opportunistic infections (e.g., trimethoprim/sulfamethoxozole for Pneumocystis jirovecii) should also be considered, just as calcium and vitamin D supplementation to avoid osteoporosis and proton pump inhibitors for gastric toxicity. The role of antifungal prophylaxis with fluconazole is less clear [150].

In addition, all other pharmacological and non-pharmacological symptomatic therapies, necessary for the management of the patient's symptoms, must be adopted (e.g., oxygen therapy, therapy for cough, dyspnea, depression, anorexia, pain or any other potential associated symptoms and, of no lesser importance, pulmonary rehabilitation) [153].

\section{Conclusions}

The clinical manifestations of antineoplastic-induced ILD are not specific, and the diagnosis is determined on the basis of the exclusion of other causative factors. As not all oncological treatments bear the same risk as ILD, it is important to know the percentage of risk associated with the use of each drug. The mechanism underlying the toxicity in some cases could be linked to the mechanism of action of the drug itself and is mediated by the activation of the inflammatory-cytokine cascade. Therefore, the therapy consists of steroid anti-inflammatory treatment. Several radiological patterns are used to describe ILDs, unfortunately mostly without specificity to differentiate the multitude of potential conditions; however, radiology can be useful in grading the severity and guiding therapeutic management. There is no protocol to forecast this toxicity, but some patient baseline 
conditions may increase the risk of ILD. Differential diagnosis recently became even more complicated and crucial in the context of the arising awareness about the clinical respiratory manifestations of COVID-19. It is important to promptly recognize and treat this adverse event, which in some cases can be fatal.

Author Contributions: Study concept and design: S.C. and A.Z.; Drafting of the manuscript: S.C.; Creating tables and figures: M.F., S.N., S.C., G.C., and G.S.; Critical revision of the manuscript for important intellectual content: M.F., S.N., G.C., T.P., C.B., and G.S.; Study supervision: C.B., G.S., and A.Z. All authors have read and agreed to the published version of the manuscript.

Funding: This research received no external funding.

Institutional Review Board Statement: Not applicable.

Informed Consent Statement: Not applicable.

Data Availability Statement: No new data were created or analyzed in this study. Data sharing is not applicable to this article.

Conflicts of Interest: The authors declare no conflict of interest.

\section{References}

1. Lee, L.Y.; Cazier, J.B.; Angelis, V.; Arnold, R.; Bisht, V.; Campton, N.A.; Chackathayil, J.; Cheng, V.W.; Curley, H.M.; Fittall, M.W.; et al. COVID-19 mortality in patients with cancer on chemotherapy or other anticancer treatments: A prospective cohort study. Lancet 2020, 395, 1919-1926. [CrossRef]

2. Malik, Y.S.; Kumar, N.; Sircar, S.; Kaushik, R.; Bhat, S.; Dhama, K.; Gupta, P.; Goyal, K.; Singh, M.P.; Ghoshal, U.; et al. Coronavirus Disease Pandemic (COVID-19): Challenges and a Global Perspective. Pathogens 2020, 9, 519. [CrossRef]

3. Kalchiem-Dekel, O.; Galvin, J.R.; Burke, A.P.; Atamas, S.P.; Todd, N.W. Interstitial Lung Disease and Pulmonary Fibrosis: A Practical Approach for General Medicine Physicians with Focus on the Medical History. J. Clin. Med. 2018, 7, 476. [CrossRef] [PubMed]

4. Van Barneveld, P.W.; van der Mark, T.W.; Sleijfer, D.T.; Mulder, N.H.; Koops, H.S.; Sluiter, H.J.; Peset, R. Predictive factors for bleomycin-induced pneumonitis. Am. Rev. Respir. Dis. 1984, 130, 1078-1081.

5. Twohig, K.J.; Matthay, R.A. Pulmonary effects of cytotoxic agents other than bleomycin. Clin. Chest Med. 1990, 11, 31-54.

6. O'Sullivan, J.M.; Huddart, R.A.; Norman, A.R.; Nicholls, J.; Dearnaley, D.P.; Horwich, A. Predicting the risk of bleomycin lung toxicity in patients with germ-cell tumours. Ann. Oncol. 2003, 14, 91-96. [CrossRef] [PubMed]

7. Knudsen, L.; Lopez-Rodriguez, E.; Berndt, L.; Steffen, L.; Ruppert, C.; Bates, J.H.T.; Ochs, M.; Smith, B.J. Alveolar Micromechanics in Bleomycin-induced Lung Injury. Am. J. Respir. Cell Mol. Biol. 2018, 59, 757-769. [CrossRef] [PubMed]

8. Ochoa, R.; Bejarano, P.A.; Glück, S.; Montero, A.J. Pneumonitis and pulmonary fibrosis in a patient receiving adjuvant docetaxel and cyclophosphamide for stage 3 breast cancer: A case report and literature review. J. Med. Case Rep. 2012, 6, 413. [CrossRef]

9. Fragoulis, G.E.; Conway, R.; Nikiphorou, E. Methotrexate and interstitial lung disease: Controversies and questions. A narrative review of the literature. Rheumatology 2019, 58, 1900-1906. [CrossRef] [PubMed]

10. Imokawa, S.; Colby, T.V.; Leslie, K.O.; Helmers, R.A. Methotrexate pneumonitis: Review of the literature and histopathological findings in nine patients. Eur. Respir. J. 2000, 15, 373-381. [CrossRef]

11. D'Elia, T. Methotrexate-induced pneumonitis: Heterogeneity of bronchoalveolar lavage and differences between cancer and rheumatoid arthritis. Inflamm. Allergy Drug Targets 2014, 13, 25-33. [CrossRef] [PubMed]

12. Barlési, F.; Villani, P.; Doddoli, C.; Gimenez, C.; Kleisbauer, J.P. Gemcitabine-induced severe pulmonary toxicity. Fundam. Clin. Pharmacol. 2004, 18, 85-91. [CrossRef] [PubMed]

13. Tamiya, A.; Naito, T.; Miura, S.; Morii, S.; Tsuya, A.; Nakamura, Y.; Kaira, K.; Murakami, H.; Takahashi, T.; Yamamoto, N.; et al. Interstitial lung disease associated with docetaxel in patients with advanced non-small cell lung cancer. Anticancer Res. 2012, 32, 1103-1106.

14. Singavi, A.K.; Ramalingam, V.; George, B. Etanercept for Treatment of Taxane-Induced Pneumonitis. J. Oncol. Pract. 2019, 15, 556-557. [CrossRef] [PubMed]

15. Thomas, A.L.; Cox, G.; Sharma, R.A.; Steward, W.P.; Shields, F.; Jeyapalan, K.; Muller, S.; O’Byrne, K.J. Gemcitabine and paclitaxel associated pneumonitis in non-small cell lung cancer: Report of a phase I/II dose-escalating study. Eur. J. Cancer 2000, 36, 2329-2334. [CrossRef]

16. Delanoy, N.; Pécuchet, N.; Fabre, E.; Combe, P.; Juvin, K.; Pujade-Lauraine, E.; Oudard, S. Bleomycin-Induced Pneumonitis in the Treatment of Ovarian Sex Cord-Stromal Tumors: A Systematic Review and Meta-analysis. Int. J. Gynecol. Cancer 2015, 25, 1593-1598. [CrossRef] 
17. Necchi, A.; Miceli, R.; Oualla, K.; Sonpavde, G.; Giannatempo, P.; Raggi, D.; Nicolai, N.; Boffi, R.; Busia, A.; Mariani, L.; et al. Effect of Bleomycin Administration on the Development of Pulmonary Toxicity in Patients with Metastatic Germ Cell Tumors Receiving First-Line Chemotherapy: A Meta-Analysis of Randomized Studies. Clin. Genitourin. Cancer 2017, 15, 213-220.e5. [CrossRef] [PubMed]

18. Okuno, S.H.; Frytak, S. Mitomycin lung toxicity: Acute and chronic phases. Am. J. Clin. Oncol. 1997, 20, 282-284. [CrossRef]

19. Linette, D.C.; McGee, K.H.; McFarland, J.A. Mitomycin-induced pulmonary toxicity: Case report and review of the literature. Ann. Pharmacother. 1992, 26, 481-484. [CrossRef] [PubMed]

20. Jacobs, C.; Slade, M.; Lavery, B. Doxorubicin and BOOP. A possible near fatal association. Clin. Oncol. R. Coll. Radiol. 2002, 14, 262. [CrossRef] [PubMed]

21. Baker, W.J.; Fistel, S.J.; Jones, R.V.; Weiss, R.B. Interstitial pneumonitis associated with ifosfamide therapy. Cancer 1990, 65, 2217-2221. [CrossRef]

22. Till, B.G.; Madtes, D.K. BCNU-associated pneumonitis: Portrait of a toxicity. Leuk. Lymphoma 2012, 53, 1019-1020. [CrossRef]

23. Maldonado, F.; Limper, A.H.; Lim, K.G.; Aubrey, M.C. Temozolomide-associated organizing pneumonitis. Mayo Clin. Proc. 2007, 82, 771-773. [CrossRef]

24. Koschel, D.; Handzhiev, S.; Leucht, V.; Holotiuk, O.; Fisseler-Eckhoff, A.; Höffken, G. Hypersensitivity pneumonitis associated with the use of temozolomide. Eur. Respir. J. 2009, 33, 931-934. [CrossRef]

25. Ideguchi, H.; Kojima, K.; Hirosako, S.; Ichiyasu, H.; Fujii, K.; Kohrogi, H. Cisplatin-induced eosinophilic pneumonia. Case Rep. Pulmonol. 2014, 2014, 209732. [CrossRef]

26. Hardy, D.; Cormier, J.N.; Xing, Y.; Liu, C.C.; Xia, R.; Du, X.L. Chemotherapy-associated toxicity in a large cohort of elderly patients with non-small cell lung cancer. J. Thorac. Oncol. 2010, 5, 90-98. [CrossRef]

27. Moskovitz, M.; Wollner, M.; Haim, N. Oxaliplatin-Induced Pulmonary Toxicity in Gastrointestinal Malignancies: Two Case Reports and Review of the Literature. Case Rep. Oncol. Med. 2015, 2015, 341064. [CrossRef]

28. Watkins, J.; Slade, J.H.; Phan, A.; Eng, C.; Weissferdt, A.; Overman, M.J. Fatal diffuse alveolar damage associated with oxaliplatin administration. Clin. Colorectal Cancer 2011, 10, 198-202. [CrossRef]

29. Waters, M.J.; Sukumaran, S.; Karapetis, C.S. Pemetrexed-Induced Interstitial Pneumonitis: A Case Study and Literature Review. World J. Oncol. 2014, 5, 232-236. [CrossRef] [PubMed]

30. Hochstrasser, A.; Benz, G.; Joerger, M.; Templeton, A.; Brutsche, M.; Früh, M. Interstitial pneumonitis after treatment with pemetrexed: A rare event? Chemotherapy 2012, 58, 84-88. [CrossRef]

31. Roychowdhury, D.F.; Cassidy, C.A.; Peterson, P.; Arning, M. A report on serious pulmonary toxicity associated with gemcitabinebased therapy. Investig. New Drugs 2002, 20, 311-315. [CrossRef]

32. Kouroussis, C.; Mavroudis, D.; Kakolyris, S.; Voloudaki, A.; Kalbakis, K.; Souglakos, J.; Agelaki, S.; Malas, K.; Bozionelou, V.; Georgoulias, V. High incidence of pulmonary toxicity of weekly docetaxel and gemcitabine in patients with non-small cell lung cancer: Results of a dose-finding study. Lung Cancer 2004, 44, 363-368. [CrossRef] [PubMed]

33. Suzuki, H.; Hirashima, T.; Kobayashi, M.; Sasada, S.; Okamoto, N.; Uehara, N.; Matsuura, Y.; Tamiya, M.; Morishita, N.; Higashiguchi, M.; et al. Effect of topotecan as second-line chemotherapy for small cell lung cancer patients with interstitial lung disease. J. Chemother. 2011, 23, 367-370. [CrossRef] [PubMed]

34. Ozawa, Y.; Koda, K.; Akahori, D.; Matsui, T.; Hasegawa, H.; Kakutani, T.; Amano, T.; Tanahashi, M.; Niwa, H.; Kunimoto, Y.; et al. Preexisting Interstitial Lung Disease and Lung Injury Associated with Irinotecan in Patients with Neoplasms. Anticancer Res. 2018, 38, 5937-5941. [CrossRef]

35. Yoshii, N.; Suzuki, T.; Nagashima, M.; Kon, A.; Kakihata, K.; Gemma, A. A Clarification of clinical features of interstitial lung disease induced by irinotecan based on postmarketing surveillance data and spontaneous reports. Anticancer Drugs 2011, 22, 563-568. [CrossRef] [PubMed]

36. Michielin, O.; Udry, E.; Périard, D.; Matzinger, O.; Lobrinus, J.A.; Stupp, R. Irinotecan-induced interstitial pneumonia. Lancet Oncol. 2004, 5, 322-324. [CrossRef]

37. Gurjal, A.; An, T.; Valdivieso, M.; Kalemkerian, G.P. Etoposide-induced pulmonary toxicity. Lung Cancer 1999, 26, 109-112. [CrossRef]

38. Bielopolski, D.; Evron, E.; Moreh-Rahav, O.; Landes, M.; Stemmer, S.M.; Salamon, F. Paclitaxel-induced pneumonitis in patients with breast cancer: Case series and review of the literature. J. Chemother. 2017, 29, 113-117. [CrossRef]

39. Ostoros, G.; Pretz, A.; Fillinger, J.; Soltesz, I.; Dome, B. Fatal pulmonary fibrosis induced by paclitaxel: A case report and review of the literature. Int. J. Gynecol. Cancer 2006, 16 (Suppl. 1), 391-393. [CrossRef]

40. Nagata, S.; Ueda, N.; Yoshida, Y.; Matsuda, H.; Maehara, Y. Severe interstitial pneumonitis associated with the administration of taxanes. J. Infect. Chemother. 2010, 16, 340-344. [CrossRef]

41. Yanagitani, N.; Shimizu, Y.; Kaira, K.; Tatsuno, S.; Sunaga, N.; Ishizuka, T.; Mori, M. Pulmonary toxicity associated with vinorelbine-based chemotherapy in breast cancer. Gan Kagaku Ryoho Cancer Chemother. 2008, 35, 1619-1621.

42. Barber, N.A.; Ganti, A.K. Pulmonary toxicities from targeted therapies: A review. Target. Oncol. 2011, 6, 235-243. [CrossRef]

43. FDA.GOV. Available online: https://www.fda.gov/drugs/drug-safety-and-availability/fda-warns-about-rare-severe-lunginflammation-ibrance-kisqali-and-verzenio-breast-cancer (accessed on 13 December 2020). 
44. Ding, P.N.; Lord, S.J.; Gebski, V.; Links, M.; Bray, V.; Gralla, R.J.; Yang, J.C.; Lee, C.K. Risk of Treatment-Related Toxicities from EGFR Tyrosine Kinase Inhibitors: A Meta-analysis of Clinical Trials of Gefitinib, Erlotinib, and Afatinib in Advanced EGFR-Mutated Non-Small Cell Lung Cancer. J. Thorac. Oncol. 2017, 12, 633-643. [CrossRef] [PubMed]

45. Qi, W.X.; Sun, Y.J.; Shen, Z.; Yao, Y. Risk of interstitial lung disease associated with EGFR-TKIs in advanced non-small-cell lung cancer: A meta-analysis of 24 phase III clinical trials. J. Chemother. 2015, 27, 40-45. [CrossRef]

46. Soria, J.C.; Ohe, Y.; Vansteenkiste, J.; Reungwetwattana, T.; Chewaskulyong, B.; Lee, K.H.; Dechaphunkul, A.; Imamura, F.; Nogami, N.; Kurata, T.; et al. Osimertinib in Untreated EGFR-Mutated Advanced Non-Small-Cell Lung Cancer. N. Engl. J. Med. 2018, 378, 113-125. [CrossRef] [PubMed]

47. Pellegrino, B.; Facchinetti, F.; Bordi, P.; Silva, M.; Gnetti, L.; Tiseo, M. Lung Toxicity in Non-Small-Cell Lung Cancer Patients Exposed to ALK Inhibitors: Report of a Peculiar Case and Systematic Review of the Literature. Clin. Lung Cancer 2018, 19, e151-e161. [CrossRef]

48. Yoneda, K.Y.; Scranton, J.R.; Cadogan, M.A.; Tassell, V.; Nadanaciva, S.; Wilner, K.D.; Stollenwerk, N.S. Interstitial lung disease associated with crizotinib in patients with advanced non-small-cell lung cancer: Independent review of four PROFILE trials. Clin. Lung Cancer 2017, 18, 472-479. [CrossRef]

49. Créquit, P.; Wislez, M.; Feith, J.F.; Rozensztajn, N.; Jabot, L.; Friard, S.; Lavole, A.; Gounant, V.; Fillon, J.; Antoine, M.; et al. Crizotinib associated with ground-glass opacity predominant pattern interstitial lung disease. J. Thorac. Oncol. 2015, 10, 1148-1155. [CrossRef] [PubMed]

50. Ng, T.L.; Narasimhan, N.; Gupta, N.; Venkatakrishnan, K.; Kerstein, D.; Camidge, D.R. Early-Onset Pulmonary Events Associated with Brigatinib Use in Advanced NSCLC. J. Thorac. Oncol. 2020, 15, 1190-1199. [CrossRef] [PubMed]

51. Bedi, S.; Khan, S.A.; AbuKhader, M.M.; Alam, P.; Siddiqui, N.A.; Husain, A. A comprehensive review on Brigatinib-A wonder drug for targeted cancer therapy in non-small cell lung cancer. Saudi Pharm. J. 2018, 26, 755-763. [CrossRef]

52. Hackshaw, M.D.; Danysh, H.E.; Singh, J.; Ritchey, M.E.; Ladner, A.; Taitt, C.; Camidge, D.R.; Iwata, H.; Powell, C.A. Incidence of pneumonitis/interstitial lung disease induced by HER2-targeting therapy for HER2-positive metastatic breast cancer. Breast Cancer Res. Treat. 2020, 183, 23-39. [CrossRef]

53. Murthy, R.K.; Loi, S.; Okines, A.; Paplomata, E.; Hamilton, E.; Hurvitz, S.A.; Lin, N.U.; Borges, V.; Abramson, V.; Anders, C.; et al. Tucatinib, Trastuzumab, and Capecitabine for HER2-Positive Metastatic Breast Cancer. N. Engl. J. Med. 2020, 382, 597-609. [CrossRef]

54. Chan, A.; Delaloge, S.; Holmes, F.A.; Moy, B.; Iwata, H.; Harvey, V.J.; Robert, N.J.; Silovski, T.; Gokmen, E.; von Minckwitz, G.; et al. Neratinib after trastuzumab-based adjuvant therapy in patients with HER2-positive breast cancer (ExteNET): A multicentre, randomised, double-blind, placebo-controlled, phase 3 trial. Lancet Oncol. 2016, 17, 367-377. [CrossRef]

55. Myung, H.J.; Jeong, S.H.; Kim, J.W.; Kim, H.S.; Jang, J.H.; Yoon, H.I.; Kim, J.S. Sorafenib-induced interstitial pneumonitis in a patient with hepatocellular carcinoma: A case report. Gut Liver 2010, 4, 543-546. [CrossRef] [PubMed]

56. Boyle, H.J.; Chatté, G.; Rivoire, M.; Fléchon, A. Lung toxicity in a patient treated with sunitinib. Eur. Respir. J. 2012, 40, 1300-1303. [CrossRef] [PubMed]

57. Ide, S.; Sakamoto, N.; Hara, S.; Hara, A.; Kakugawa, T.; Nakamura, Y.; Futsuki, Y.; Izumikawa, K.; Ishimatsu, Y.; Yanagihara, K.; et al. Interstitial Lung Disease Induced by Pazopanib Treatment. Intern. Med. 2017, 56, 79-83. [CrossRef]

58. Ohnishi, K.; Sakai, F.; Kudoh, S.; Ohno, R. Twenty-seven cases of drug-induced interstitial lung disease associated with imatinib mesylate. Leukemia 2006, 20, 1162-1164. [CrossRef] [PubMed]

59. Flaherty, K.T.; Robert, C.; Hersey, P.; Nathan, P.; Garbe, C.; Milhem, M.; Demidov, L.V.; Hassel, J.C.; Rutkowski, P.; Mohr, P.; et al. Improved survival with MEK inhibition in BRAF-mutated melanoma. N. Engl. J. Med. 2012, 367, 107-114. [CrossRef] [PubMed]

60. Long, G.V.; Stroyakovskiy, D.; Gogas, H.; Levchenko, E.; de Braud, F.; Larkin, J.; Garbe, C.; Jouary, T.; Hauschild, A.; Grob, J.J.; et al. Dabrafenib and trametinib versus dabrafenib and placebo for Val600 BRAF-mutant melanoma: A multicentre, double-blind, phase 3 randomised controlled trial. Lancet 2015, 386, 444-451. [CrossRef]

61. Robert, C.; Karaszewska, B.; Schachter, J.; Rutkowski, P.; Mackiewicz, A.; Stroiakovski, D.; Lichinitser, M.; Dummer, R.; Grange, F.; Mortier, L.; et al. Improved overall survival in melanoma with combined dabrafenib and trametinib. N. Engl. J. Med. 2015, 372, 30-39. [CrossRef]

62. André, F.; Ciruelos, E.; Rubovszky, G.; Campone, M.; Loibl, S.; Rugo, H.S.; Iwata, H.; Conte, P.; Mayer, I.A.; Kaufman, B.; et al. Alpelisib for PIK3CA-Mutated, Hormone Receptor-Positive Advanced Breast Cancer. N. Engl. J. Med. 2019, 380, 1929-1940. [CrossRef]

63. Nozawa, M.; Ohzeki, T.; Tamada, S.; Hongo, F.; Anai, S.; Fujimoto, K.; Miki, T.; Nakatani, T.; Fukasawa, S.; Uemura, H. Differences in adverse event profiles between everolimus and temsirolimus and the risk factors for non-infectious pneumonitis in advanced renal cell carcinoma. Int. J. Clin. Oncol. 2015, 20, 790-795. [CrossRef] [PubMed]

64. Motzer, R.J.; Escudier, B.; Oudard, S.; Hutson, T.E.; Porta, C.; Bracarda, S.; Grünwald, V.; Thompson, J.A.; Figlin, R.A.; Hollaender, N.; et al. Phase 3 trial of everolimus for metastatic renal cell carcinoma: Final results and analysis of prognostic factors. Cancer 2010, 116, 4256-4265. [CrossRef] [PubMed]

65. Pavel, M.E.; Hainsworth, J.D.; Baudin, E.; Peeters, M.; Hörsch, D.; Winkler, R.E.; Klimovsky, J.; Lebwohl, D.; Jehl, V.; Wolin, E.M.; et al. RADIANT-2 Study Group. Everolimus plus octreotide long-acting repeatable for the treatment of advanced neuroendocrine tumours associated with carcinoid syndrome (RADIANT-2): A randomised, placebo-controlled, phase 3 study. Lancet 2011, 378, 2005-2012. [CrossRef] 
66. Yao, J.C.; Shah, M.H.; Ito, T.; Bohas, C.L.; Wolin, E.M.; Van Cutsem, E.; Hobday, T.J.; Okusaka, T.; Capdevila, J.; de Vries, E.G.; et al. Everolimus for advanced pancreatic neuroendocrine tumors. N. Engl. J. Med. 2011, 364, 514-523, (RADIANT-3). [CrossRef] [PubMed]

67. Atkins, M.B.; Hidalgo, M.; Stadler, W.M.; Logan, T.F.; Dutcher, J.P.; Hudes, G.R.; Park, Y.; Liou, S.H.; Marshall, B.; Boni, J.P.; et al. Randomized phase II study of multiple dose levels of CCI-779, a novel mammalian target of rapamycin kinase inhibitor, in patients with advanced refractory renal cell carcinoma. J. Clin. Oncol. 2004, 22, 909-918. [CrossRef]

68. Bellmunt, J.; Szczylik, C.; Feingold, J.; Strahs, A.; Berkenblit, A. Temsirolimus safety profile and management of toxic effects in patients with advanced renal cell carcinoma and poor prognostic features. Ann. Oncol. 2008, 19, 1387-1392. [CrossRef]

69. Costa, R.; Costa-Filho, R.B.; Talamantes, S.M.; Queiroga, F., Jr.; Campello, E.C.; Cartaxo, H.; Costa, R.B. Interstitial Pneumonitis Secondary to Trastuzumab: A Case Report and Literature Review. Case Rep. Oncol. 2017, 10, 524-530. [CrossRef]

70. Sugaya, A.; Ishiguro, S.; Mitsuhashi, S.; Abe, M.; Hashimoto, I.; Kaburagi, T.; Kojima, H. Interstitial lung disease associated with trastuzumab monotherapy: A report of 3 cases. Mol. Clin. Oncol. 2017, 6, 229-232. [CrossRef]

71. Piccart-Gebhart, M.J.; Procter, M.; Leyland-Jones, B.; Goldhirsch, A.; Untch, M.; Smith, I.; Gianni, L.; Baselga, J.; Bell, R.; Jackisch, C.; et al. Trastuzumab after adjuvant chemotherapy in HER2-positive breast cancer. N. Engl. J. Med. 2005, 353, 1659-1672. [CrossRef]

72. Swain, S.M.; Kim, S.B.; Cortés, J.; Ro, J.; Semiglazov, V.; Campone, M.; Ciruelos, E.; Ferrero, J.M.; Schneeweiss, A.; Knott, A.; et al. Pertuzumab, trastuzumab, and docetaxel for HER2-positive metastatic breast cancer (CLEOPATRA study): Overall survival results from a randomised, double-blind, placebo-controlled, phase 3 study. Lancet Oncol. 2013, 14, 461-471. [CrossRef]

73. Hoag, J.B.; Azizi, A.; Doherty, T.J.; Lu, J.; Willis, R.E.; Lund, M.E. Association of cetuximab with adverse pulmonary events in cancer patients: A comprehensive review. J. Exp. Clin. Cancer Res. 2009, 28, 113. [CrossRef] [PubMed]

74. Chua, W.; Peters, M.; Loneragan, R.; Clarke, S. Cetuximab-associated pulmonary toxicity. Clin. Colorectal. Cancer 2009, 8, 118-120. [CrossRef]

75. Arora, R.; Kisiel, M.; MacColl, C. Panitumumab-induced pulmonary toxicity. Curr. Oncol. 2019, 26, e700-e702. [CrossRef]

76. Sekimoto, Y.; Kato, M.; Shukuya, T.; Koyama, R.; Nagaoka, T.; Takahashi, K. Bevacizumab-induced chronic interstitial pneumonia during maintenance therapy in non-small cell lung cancer. Respirol. Case Rep. 2016, 4, e0151. [CrossRef] [PubMed]

77. Wilke, H.; Muro, K.; Van Cutsem, E.; Oh, S.C.; Bodoky, G.; Shimada, Y.; Hironaka, S.; Sugimoto, N.; Lipatov, O.; Kim, T.Y.; et al. Ramucirumab plus paclitaxel versus placebo plus paclitaxel in patients with previously treated advanced gastric or gastro-oesophageal junction adenocarcinoma (RAINBOW): A double-blind, randomised phase 3 trial. Lancet Oncol. 2014, 15, 1224-1235. [CrossRef]

78. Fuchs, C.S.; Tomasek, J.; Yong, C.J.; Dumitru, F.; Passalacqua, R.; Goswami, C.; Safran, H.; Dos Santos, L.V.; Aprile, G.; Ferry, D.R.; et al. Ramucirumab monotherapy for previously treated advanced gastric or gastro-oesophageal junction adenocarcinoma (REGARD): An international, randomised, multicentre, placebo-controlled, phase 3 trial. Lancet 2014, 383, 31-39. [CrossRef]

79. Koyama, N.; Katayanagi, S.; Kawachi, S. Pre-existing interstitial lung disease as a risk factor for pneumonitis associated with ramucirumab and paclitaxel in patients with gastric cancer: The impact of usual interstitial pneumonia. PLoS ONE 2018, 13, e0198886. [CrossRef]

80. Hurvitz, S.A.; Dirix, L.; Kocsis, J.; Bianchi, G.V.; Lu, J.; Vinholes, J.; Guardino, E.; Song, C.; Tong, B.; Ng, V.; et al. Phase II randomized study of trastuzumab emtansine versus trastuzumab plus docetaxel in patients with human epidermal growth factor receptor 2-positive metastatic breast cancer. J. Clin. Oncol. 2013, 31, 1157-1163. [CrossRef]

81. Rosenberg, J.E.; O’Donnell, P.H.; Balar, A.V.; McGregor, B.A.; Heath, E.I.; Yu, E.Y.; Galsky, M.D.; Hahn, N.M.; Gartner, E.M.; Pinelli, J.M.; et al. Pivotal Trial of Enfortumab Vedotin in Urothelial Carcinoma After Platinum and Anti-Programmed Death 1/Programmed Death Ligand 1 Therapy. J. Clin. Oncol. Off. J. Am. Soc. Clin. Oncol. 2019, 37, 2592-2600. [CrossRef]

82. Ozaki, Y.; Masuda, J.; Takano, T. Sacituzumab Govitecan-hziy in Triple-Negative Breast Cancer. N. Engl. J. Med. 2019, 380, 2382. [CrossRef]

83. Modi, S.; Saura, C.; Yamashita, T.; Park, Y.H.; Kim, S.B.; Tamura, K.; Andre, F.; Iwata, H.; Ito, Y.; Tsurutani, J.; et al. Trastuzumab Deruxtecan in Previously Treated HER2-Positive Breast Cancer. N. Engl. J. Med. 2020, 382, 610-621. [CrossRef]

84. Tamura, K.; Tsurutani, J.; Takahashi, S.; Iwata, H.; Krop, I.E.; Redfern, C.; Sagara, Y.; Doi, T.; Park, H.; Murthy, R.K.; et al. Trastuzumab deruxtecan (DS-8201a) in patients with advanced HER2-positive breast cancer previously treated with trastuzumab emtansine: A dose-expansion, phase 1 study. Lancet Oncol. 2019, 20, 816-826. [CrossRef]

85. Hwang, H.J.; Kim, M.Y.; Choi, C.M.; Lee, J.C. Anaplastic lymphoma kinase inhibitor related pneumonitis in patients with non-small cell lung cancer: Clinical and radiologic characteristics and risk factors. Medicine 2019, 98, e18131. [CrossRef]

86. Dabydeen, D.A.; Jagannathan, J.P.; Ramaiya, N.; Krajewski, K.; Schutz, F.A.; Cho, D.C.; Pedrosa, I.; Choueiri, T.K. Pneumonitis associated with $\mathrm{mTOR}$ inhibitors therapy in patients with metastatic renal cell carcinoma: Incidence, radiographic findings and correlation with clinical outcome. Eur. J. Cancer 2012, 48, 1519-1524. [CrossRef]

87. Baselga, J.; Campone, M.; Piccart, M.; Burris, H.A., 3rd; Rugo, H.S.; Sahmoud, T.; Noguchi, S.; Gnant, M.; Pritchard, K.I.; Lebrun, F.; et al. Everolimus in postmenopausal hormone-receptor-positive advanced breast cancer. N. Engl. J. Med. 2012, 366, 520-529. [CrossRef]

88. Morelon, E.; Stern, M.; Israël-Biet, D.; Correas, J.M.; Danel, C.; Mamzer-Bruneel, M.F.; Peraldi, M.N.; Kreis, H. Characteristics of sirolimus-associated interstitial pneumonitis in renal transplant patients. Transplantation 2001, 72, 787-790. [CrossRef] 
89. Säemann, M.D.; Haidinger, M.; Hecking, M.; Hörl, W.H.; Weichhart, T. The multifunctional role of mTOR in innate immunity: Implications for transplant immunity. Am. J. Transpl. 2009, 9, 2655-2661. [CrossRef]

90. EMA Prescribing Information: Everolimus. Available online: https://www.ema.europa.eu/en/documents/productinformation/afinitor-epar-product-information_en.pdf (accessed on 13 December 2020).

91. Gong, C.; Xiao, Q.; Li, Y.; Gu, Y.; Zhang, J.; Wang, L.; Cao, J.; Tao, Z.; Zhao, Y.; Xie, Y.; et al. Everolimus-Related Pneumonitis in Patients with Metastatic Breast Cancer: Incidence, Radiographic Patterns, and Relevance to Clinical Outcome. Oncologist 2020. [CrossRef] [PubMed]

92. Mizuno, R.; Asano, K.; Mikami, S.; Nagata, H.; Kaneko, G.; Oya, M. Patterns of interstitial lung disease during everolimus treatment in patients with metastatic renal cell carcinoma. Jpn. J. Clin. Oncol. 2012, 42, 442-446. [CrossRef] [PubMed]

93. Sakai, F.; Johkoh, T.; Kusumoto, M.; Arakawa, H.; Takahashi, M. Drug-induced interstitial lung disease in molecular targeted therapies: High-resolution CT findings. Int. J. Clin. Oncol. 2012, 17, 542-550. [CrossRef] [PubMed]

94. Alvarez, R.H.; Bechara, R.I.; Naughton, M.J.; Adachi, J.A.; Reuben, J.M. Emerging Perspectives on mTOR Inhibitor-Associated Pneumonitis in Breast Cancer. Oncologist 2018, 23, 660-669. [CrossRef]

95. FDA Highlights of Prescribing Information: Alpelisib. Version 5.2019. Available online: https://www.accessdata.fda.gov/ drugsatfda_docs/label/2019/212526s000lbl.pdf (accessed on 13 December 2020).

96. Nishino, M.; Hatabu, H.; Sholl, L.M.; Ramaiya, N.H. Thoracic Complications of Precision Cancer Therapies: A Practical Guide for Radiologists in the New Era of Cancer Care. Radiographics 2017, 37, 1371-1387. [CrossRef]

97. Wang, H.; Guo, X.; Zhou, J.; Li, Y.; Duan, L.; Si, X.; Zhang, L.; Liu, X.; Wang, M.; Shi, J.; et al. Clinical diagnosis and treatment of immune checkpoint inhibitor-associated pneumonitis. Thorac. Cancer 2020, 11, 191-197. [CrossRef]

98. Postow, M.A.; Sidlow, R.; Hellmann, M.D. Immune-related adverse events associated with immune checkpoint blockade. N. Engl. J. Med. 2018, 378, 158-168. [CrossRef]

99. Su, Q.; Zhu, E.C.; Wu, J.B.; Li, T.; Hou, Y.L.; Wang, D.Y.; Gao, Z.H. Risk of Pneumonitis and Pneumonia Associated With Immune Checkpoint Inhibitors for Solid Tumors: A Systematic Review and Meta-Analysis. Front. Immunol. 2019, 10, 108. [CrossRef]

100. Okada, N.; Matsuoka, R.; Sakurada, T.; Mitsuhiro, G.; Masayuki, C.; Kenta, Y.; Yoshito, Z.; Yasuhiko, N.; Keisuke, I. Risk factors of immune checkpoint inhibitor-related interstitial lung disease in patients with lung cancer: A single-institution retrospective study. Sci. Rep. 2020, 10, 13773. [CrossRef]

101. Nishino, M.; Hatabu, H.; Hodi, F.S. Imaging of Cancer Immunotherapy: Current Approaches and Future Directions. Radiology 2019, 290, 9-22. [CrossRef]

102. Sugano, T.; Seike, M.; Saito, Y.; Kashiwada, T.; Terasaki, Y.; Takano, N.; Hisakane, K.; Takahashi, S.; Tanaka, T.; Takeuchi, S.; et al. Immune checkpoint inhibitor-associated interstitial lung diseases correlate with better prognosis in patients with advanced non-small-cell lung cancer. Thorac. Cancer 2020, 11, 1052-1060. [CrossRef]

103. Robert, C.; Long, G.V.; Brady, B.; Dutriaux, C.; Maio, M.; Mortier, L.; Hassel, J.C.; Rutkowski, P.; McNeil, C.; Kalinka-Warzocha, E.; et al. Nivolumab in previously untreated melanoma without BRAF mutation. N. Engl. J. Med. 2015, 372, 320-330. [CrossRef] [PubMed]

104. Weber, J.; Mandala, M.; Del Vecchio, M.; Gogas, H.J.; Arance, A.M.; Cowey, C.L.; Dalle, S.; Schenker, M.; Chiarion-Sileni, V.; Marquez-Rodas, I.; et al. Adjuvant Nivolumab versus Ipilimumab in Resected Stage III or IV Melanoma. N. Engl. J. Med. 2017, 377, 1824-1835. [CrossRef] [PubMed]

105. Ferris, R.L.; Blumenschein, G., Jr.; Fayette, J.; Guigay, J.; Colevas, A.D.; Licitra, L.; Harrington, K.; Kasper, S.; Vokes, E.E.; Even, C.; et al. Nivolumab for Recurrent Squamous-Cell Carcinoma of the Head and Neck. N. Engl. J. Med. 2016, 375, $1856-1867$. [CrossRef] [PubMed]

106. Sharma, P.; Retz, M.; Siefker-Radtke, A.; Baron, A.; Necchi, A.; Bedke, J.; Plimack, E.R.; Vaena, D.; Grimm, M.O.; Bracarda, S.; et al. Nivolumab in metastatic urothelial carcinoma after platinum therapy (CheckMate 275): A multicentre, single-arm, phase 2 trial. Lancet Oncol. 2017, 18, 312-322. [CrossRef]

107. Brahmer, J.; Reckamp, K.L.; Baas, P.; Crinò, L.; Eberhardt, W.E.; Poddubskaya, E.; Antonia, S.; Pluzanski, A.; Vokes, E.E.; Holgado, E.; et al. Nivolumab versus Docetaxel in Advanced Squamous-Cell Non-Small-Cell Lung Cancer. N. Engl. J. Med. 2015, 373, 123-135. [CrossRef]

108. Borghaei, H.; Paz-Ares, L.; Horn, L.; Spigel, D.R.; Steins, M.; Ready, N.E.; Chow, L.Q.; Vokes, E.E.; Felip, E.; Holgado, E.; et al. Nivolumab versus Docetaxel in Advanced Nonsquamous Non-Small-Cell Lung Cancer. N. Engl. J. Med. 2015, 373, 1627-1639. [CrossRef] [PubMed]

109. Motzer, R.J.; Escudier, B.; McDermott, D.F.; George, S.; Hammers, H.J.; Srinivas, S.; Tykodi, S.S.; Sosman, J.A.; Procopio, G.; Plimack, E.R.; et al. CheckMate 025 Investigators. Nivolumab versus Everolimus in Advanced Renal-Cell Carcinoma. N. Engl. J. Med. 2015, 373, 18013. [CrossRef]

110. Larkin, J.; Chiarion-Sileni, V.; Gonzalez, R.; Grob, J.J.; Cowey, C.L.; Lao, C.D.; Schadendorf, D.; Dummer, R.; Smylie, M.; Rutkowski, P.; et al. Combined Nivolumab and Ipilimumab or Monotherapy in Untreated Melanoma. N. Engl. J. Med. 2015, 373, 23-34. [CrossRef]

111. Motzer, R.J.; Tannir, N.M.; McDermott, D.F.; Frontera, O.A.; Melichar, B.; Choueiri, T.K.; Plimack, E.R.; Barthélémy, P.; Porta, C.; George, S.; et al. Nivolumab plus Ipilimumab versus Sunitinib in Advanced Renal-Cell Carcinoma. N. Engl. J. Med. 2018, 378, 1277-1290. [CrossRef] 
112. Burtness, B.; Harrington, K.J.; Greil, R.; Soulières, D.; Tahara, M.; de Castro, G., Jr.; Psyrri, A.; Basté, N.; Neupane, P.; Bratland, Å.; et al. Pembrolizumab alone or with chemotherapy versus cetuximab with chemotherapy for recurrent or metastatic squamous cell carcinoma of the head and neck (KEYNOTE-048): A randomised, open-label, phase 3 study. Lancet 2019, 394, 1915-1928. [CrossRef]

113. Cohen, E.E.W.; Soulières, D.; Le Tourneau, C.; Dinis, J.; Licitra, L.; Ahn, M.J.; Soria, A.; Machiels, J.P.; Mach, N.; Mehra, R.; et al. Pembrolizumab versus methotrexate, docetaxel, or cetuximab for recurrent or metastatic head-and-neck squamous cell carcinoma (KEYNOTE-040): A randomised, open-label, phase 3 study. Lancet 2019, 393, 156-167. [CrossRef]

114. Reck, M.; Rodríguez-Abreu, D.; Robinson, A.G.; Hui, R.; Csőszi, T.; Fülöp, A.; Gottfried, M.; Peled, N.; Tafreshi, A.; Cuffe, S.; et al. Pembrolizumab versus Chemotherapy for PD-L1-Positive Non-Small-Cell Lung Cancer. N. Engl. J. Med. 2016, 375, 1823-1833. [CrossRef]

115. Herbst, R.S.; Baas, P.; Kim, D.W.; Felip, E.; Pérez-Gracia, J.L.; Han, J.Y.; Molina, J.; Kim, J.H.; Arvis, C.D.; Ahn, M.J.; et al. Pembrolizumab versus docetaxel for previously treated, PD-L1-positive, advanced non-small-cell lung cancer (KEYNOTE-010): A randomised controlled trial. Lancet 2016, 387, 1540-1550. [CrossRef]

116. Eggermont, A.M.M.; Blank, C.U.; Mandala, M.; Long, G.V.; Atkinson, V.; Dalle, S.; Haydon, A.; Lichinitser, M.; Khattak, A.; Carlino, M.S.; et al. Adjuvant Pembrolizumab versus Placebo in Resected Stage III Melanoma. N. Engl. J. Med. 2018, 378, 1789-1801. [CrossRef] [PubMed]

117. Robert, C.; Schachter, J.; Long, G.V.; Arance, A.; Grob, J.J.; Mortier, L.; Daud, A.; Carlino, M.S.; McNeil, C.; Lotem, M.; et al. Pembrolizumab versus Ipilimumab in Advanced Melanoma. N. Engl. J. Med. 2015, 372, 2521-2532. [CrossRef]

118. Ribas, A.; Puzanov, I.; Dummer, R.; Schadendorf, D.; Hamid, O.; Robert, C.; Hodi, F.S.; Schachter, J.; Pavlick, A.C.; Lewis, K.D.; et al. Pembrolizumab versus investigator-choice chemotherapy for ipilimumab-refractory melanoma (KEYNOTE-002): A randomised, controlled, phase 2 trial. Lancet Oncol. 2015, 16, 908-918. [CrossRef]

119. Bellmunt, J.; de Wit, R.; Vaughn, D.J.; Fradet, Y.; Lee, J.L.; Fong, L.; Vogelzang, N.J.; Climent, M.A.; Petrylak, D.P.; Choueiri, T.K.; et al. Pembrolizumab as Second-Line Therapy for Advanced Urothelial Carcinoma. N. Engl. J. Med. 2017, 376, 1015-1026. [CrossRef]

120. Gandhi, L.; Rodríguez-Abreu, D.; Gadgeel, S.; Esteban, E.; Felip, E.; De Angelis, F.; Domine, M.; Clingan, P.; Hochmair, M.J.; Powell, S.F.; et al. Pembrolizumab plus Chemotherapy in Metastatic Non-Small-Cell Lung Cancer. N. Engl. J. Med. 2018, 378, 2078-2092. [CrossRef] [PubMed]

121. Paz-Ares, L.; Luft, A.; Vicente, D.; Tafreshi, A.; Gümüş, M.; Mazières, J.; Hermes, B.; Çay Şenler, F.; Csőszi, T.; Fülöp, A.; et al. Pembrolizumab plus Chemotherapy for Squamous Non-Small-Cell Lung Cancer. N. Engl. J. Med. 2018, 379, 2040-2051. [CrossRef]

122. Rini, B.I.; Plimack, E.R.; Stus, V.; Gafanov, R.; Hawkins, R.; Nosov, D.; Pouliot, F.; Alekseev, B.; Soulières, D.; Melichar, B.; et al. Pembrolizumab plus Axitinib versus Sunitinib for Advanced Renal-Cell Carcinoma. N. Engl. J. Med. 2019, 380, $1116-1127$. [CrossRef]

123. Rosenberg, J.E.; Hoffman-Censits, J.; Powles, T.; van der Heijden, M.S.; Balar, A.V.; Necchi, A.; Dawson, N.; O’Donnell, P.H.; Balmanoukian, A.; Loriot, Y.; et al. Atezolizumab in patients with locally advanced and metastatic urothelial carcinoma who have progressed following treatment with platinum-based chemotherapy: A single-arm, multicentre, phase 2 trial. Lancet 2016, 387, 1909-1920. [CrossRef]

124. Rittmeyer, A.; Barlesi, F.; Waterkamp, D.; Park, K.; Ciardiello, F.; von Pawel, J.; Gadgeel, S.M.; Hida, T.; Kowalski, D.M.; Dols, M.C.; et al. Atezolizumab versus docetaxel in patients with previously treated non-small-cell lung cancer (OAK): A phase 3, open-label, multicentre randomised controlled trial. Lancet 2017, 389, 255-265. [CrossRef]

125. Schmid, P.; Adams, S.; Rugo, H.S.; Schneeweiss, A.; Barrios, C.H.; Iwata, H.; Diéras, V.; Hegg, R.; Im, S.A.; Shaw Wright, G.; et al. Atezolizumab and Nab-Paclitaxel in Advanced Triple-Negative Breast Cancer. N. Engl. J. Med. 2018, 379, 2108-2121. [CrossRef] [PubMed]

126. Antonia, S.J.; Villegas, A.; Daniel, D.; Vicente, D.; Murakami, S.; Hui, R.; Kurata, T.; Chiappori, A.; Lee, K.H.; de Wit, M.; et al. Overall Survival with Durvalumab after Chemoradiotherapy in Stage III NSCLC. N. Engl. J. Med. 2018, 379, 2342-2350. [CrossRef]

127. Paz-Ares, L.; Dvorkin, M.; Chen, Y.; Reinmuth, N.; Hotta, K.; Trukhin, D.; Statsenko, G.; Hochmair, M.J.; Özgüroğlu, M.; Ji, J.H.; et al. Durvalumab plus platinum-etoposide versus platinum-etoposide in first-line treatment of extensive-stage small-cell lung cancer (CASPIAN): A randomised, controlled, open-label, phase 3 trial. Lancet 2019, 394, 1929-1939. [CrossRef]

128. Kaufman, H.L.; Russell, J.; Hamid, O.; Bhatia, S.; Terheyden, P.; D’Angelo, S.P.; Shih, K.C.; Lebbé, C.; Linette, G.P.; Milella, M.; et al. Avelumab in patients with chemotherapy-refractory metastatic Merkel cell carcinoma: A multicentre, single-group, open-label, phase 2 trial. Lancet Oncol. 2016, 17, 1374-1385. [CrossRef]

129. Motzer, R.J.; Penkov, K.; Haanen, J.; Rini, B.; Albiges, L.; Campbell, M.T.; Venugopal, B.; Kollmannsberger, C.; Negrier, S.; Uemura, M.; et al. Avelumab plus Axitinib versus Sunitinib for Advanced Renal-Cell Carcinoma. N. Engl. J. Med. 2019, 380, 1103-1115. [CrossRef] [PubMed]

130. Hodi, F.S.; O’Day, S.J.; McDermott, D.F.; Weber, R.W.; Sosman, J.A.; Haanen, J.B.; Gonzalez, R.; Robert, C.; Schadendorf, D.; Hassel, J.C.; et al. Improved survival with ipilimumab in patients with metastatic melanoma. N. Engl. J. Med. 2010, 363, 711-723. [CrossRef]

131. EMA Product Information: Ipilimumab. Available online: https://www.ema.europa.eu/en/documents/product-information/ yervoy-epar-product-information_en.pdf (accessed on 13 December 2020). 
132. Khunger, M.; Rakshit, S.; Pasupuleti, V.; Hernandez, A.V.; Mazzone, P.; Stevenson, J.; Pennell, N.A.; Velcheti, V. Incidence of pneumonitis with use of programmed death 1 and programmed death-ligand 1 inhibitors in non-small cell lung cancer: A systematic review and meta-analysis of trials. Chest 2017, 152, 271-281. [CrossRef]

133. Akinleye, A.; Rasool, Z. Immune checkpoint inhibitors of PD-L1 as cancer therapeutics. J. Hematol. Oncol. 2019, 12, 92. [CrossRef]

134. Takano, T.; Ohe, Y.; Kusumoto, M.; Tateishi, U.; Yamamoto, S.; Nokihara, H.; Yamamoto, N.; Sekine, I.; Kunitoh, H.; Tamura, T.; et al. Risk factors for interstitial lung disease and predictive factors for tumor response in patients with advanced non-small cell lung cancer treated with gefitinib. Lung Cancer 2004, 45, 93-104. [CrossRef] [PubMed]

135. Abid, S.H.; Malhotra, V.; Perry, M.C. Radiation-induced and chemotherapy-induced pulmonary injury. Curr. Opin. Oncol. 2001, 13, 242-248. [CrossRef] [PubMed]

136. Blank, C.U.; Enk, A. Therapeutic use of anti-CTLA-4 antibodies. Int. Immunol. 2015, 27, 3-10. [CrossRef] [PubMed]

137. Torrisi, J.M.; Schwartz, L.H.; Gollub, M.J.; Ginsberg, M.S.; Bosl, G.J.; Hricak, H. CT findings of chemotherapy-induced toxicity: What radiologists need to know about the clinical and radiologic manifestations of chemotherapy toxicity. Radiology 2011, 258, 41-56. [CrossRef]

138. Distefano, G.; Fanzone, L.; Palermo, M.; Tiralongo, F.; Cosentino, S.; Inì, C.; Galioto, F.; Vancheri, A.; Torrisi, S.E.; Mauro, L.A.; et al. HRCT Patterns of Drug-Induced Interstitial Lung Diseases: A Review. Diagnostics 2020, 10, 244. [CrossRef]

139. Duzgun, S.A.; Durhan, G.; Demirkazik, F.B.; Akpinar, M.G.; Ariyurek, O.M. COVID-19 pneumonia: The great radiological mimicker. Insights Imaging 2020, 11, 118. [CrossRef]

140. Buchler, T.; Bomanji, J.; Lee, S.M. FDG-PET in bleomycin-induced pneumonitis following ABVD chemotherapy for Hodgkin's disease-A useful tool for monitoring pulmonary toxicity and disease activity. Haematologica 2007, 92, e120-1. [CrossRef]

141. Basu, S.; Saboury, B.; Werner, T.; Alavi, A. Clinical utility of FDG-PET and PET/CT in non-malignant thoracic disorders. Mol. Imaging Biol. 2011, 13, 1051-1060. [CrossRef]

142. Van Diessen, J.; De Ruysscher, D.; Sonke, J.J.; Damen, E.; Sikorska, K.; Reymen, B.; van Elmpt, W.; Westman, G.; Persson, G.F.; Dieleman, E.; et al. The acute and late toxicity results of a randomized phase II dose-escalation trial in non-small cell lung cancer (PET-boost trial). Radiother. Oncol. 2019, 131, 166-173. [CrossRef]

143. Willemsen, A.E.C.A.B.; Tol, J.; van Erp, N.P.; Jonker, M.A.; de Boer, M.; Meek, B.; de Jong, P.C.; van Moorsel, C.; Gerritsen, W.R.; Grutters, J.C.; et al. Prospective Study of Drug-induced Interstitial Lung Disease in Advanced Breast Cancer Patients Receiving Everolimus Plus Exemestane. Target. Oncol. 2019, 14, 441-451. [CrossRef]

144. Razzouk-Cadet, M.; Picard, A.; Grangeon-Chapon, C.; Lacour, J.P.; Montaudié, H. Nivolumab-Induced Pneumonitis in Patient with Metastatic Melanoma Showing Complete Remission on 18F-FDG PET/CT. Clin. Nucl. Med. 2019, 44, 806-807. [CrossRef]

145. Endoh, H.; Yamamoto, R.; Ichikawa, A.; Shiozawa, S.; Nishizawa, N.; Satoh, Y.; Oriuchi, N. Clinicopathological significance of false-positive lymph node status on 18F-FDG PET in lung cancer. Clin. Lung Cancer 2020. [CrossRef]

146. Erickson, B.J.; Korfiatis, P.; Akkus, Z.; Kline, T.L. Machine learning for medical imaging. Radiographics 2017, 37, 505-515. [CrossRef]

147. Carlos, F.; Uribe, S.M.; Vincent, C.; Gaudet, K.C.; Smith, P.R.-N.; Francois, B.; Sandra, E.B.; Katherine, Z. Machine Learning in Nuclear Medicine: Part 1-Introduction. J. Nucl. Med. 2019, 60, 451-458. [CrossRef]

148. Kim, R.; Meyer, K.C. Therapies for interstitial lung disease: Past, present and future. Ther. Adv. Respir. Dis. 2008, 2, 319-338. [CrossRef]

149. Vacchi, C.; Sebastiani, M.; Cassone, G.; Cerri, S.; Della Casa, G.; Salvarani, C.; Manfredi, A. Therapeutic Options for the Treatment of Interstitial Lung Disease Related to Connective Tissue Diseases. A Narrative Review. J. Clin. Med. 2020, 9, 407. [CrossRef]

150. Brahmer, J.R.; Lacchetti, C.; Schneider, B.J.; Atkins, M.B.; Brassil, K.J.; Caterino, J.M.; Chau, I.; Ernstoff, M.S.; Gardner, J.M.; Ginex, P.; et al. Management of Immune-Related Adverse Events in Patients Treated with Immune Checkpoint Inhibitor Therapy: American Society of Clinical Oncology Clinical Practice Guideline. J. Clin. Oncol. 2018, 36, 1714-1768. [CrossRef]

151. Friedman, C.F.; Proverbs-Singh, T.A.; Postow, M.A. Treatment of the Immune-Related Adverse Effects of Immune Checkpoint Inhibitors: A Review. JAMA Oncol. 2016, 2, 1346-1353. [CrossRef]

152. Nishino, M.; Hatabu, H.; Hodi, F.S.; Ramaiya, N.H. Drug-Related Pneumonitis in the Era of Precision Cancer Therapy. JCO Precis. Oncol. 2017, 1, 1-12. [CrossRef]

153. Lindell, K.O. Nonpharmacological therapies for interstitial lung disease. Curr. Pulmonol. Rep. 2018, 7, 126-132. [CrossRef] 